\title{
Mantle Pb Paradoxes: The Sulfide Solution
}

\author{
S. R. Hart and G. A. Gaetani \\ Woods Hole Oceanographic Institution, Woods Hole, MA 02543
}

\begin{abstract}
There is growing evidence that the budget of $\mathrm{Pb}$ in mantle peridotites is largely contained in sulfide, and that $\mathrm{Pb}$ partitions strongly into sulfide relative to silicate melt. In addition, there is evidence to suggest that diffusion rates of $\mathrm{Pb}$ in sulfide (solid or melt) are very fast. Given the possibility that sulfide melt 'wets' sub-solidus mantle silicates, and has very low viscosity, the implications for $\mathrm{Pb}$ behavior during mantle melting are profound. There is only sparse experimental data relating to $\mathrm{Pb}$ partitioning between sulfide and silicate, and no data on $\mathrm{Pb}$ diffusion rates in sulfides. A full understanding of $\mathrm{Pb}$ behavior in sulfide may hold the key to several long-standing and important $\mathrm{Pb}$ paradoxes and enigmas. The classical $\mathrm{Pb}$ isotope paradox arises from the fact that all known mantle reservoirs lie to the right of the Geochron, with no consensus as to the identity of the "balancing" reservoir. We propose that long-term segregation of sulfide (containing $\mathrm{Pb}$ ) to the core may resolve this paradox.

Another $\mathrm{Pb}$ paradox arises from the fact that the $\mathrm{Ce} / \mathrm{Pb}$ ratio of both OIB and MORB is greater than bulk earth, and constant at a value of 25 . The constancy of this "canonical ratio" implies similar partition coefficients for $\mathrm{Ce}$ and $\mathrm{Pb}$ during magmatic processes (Hofmann et al. 1986), whereas most experimental studies show that $\mathrm{Pb}$ is more incompatible in silicates than $\mathrm{Ce}$. Retention of $\mathrm{Pb}$ in residual mantle sulfide during melting has the potential to bring the bulk partitioning of $\mathrm{Ce}$ into equality with $\mathrm{Pb}$ if the sulfide melt/silicate melt partition coefficient for $\mathrm{Pb}$ has a value of $\sim 14$. Modeling shows that the $\mathrm{Ce} / \mathrm{Pb}$ (or $\mathrm{Nd} / \mathrm{Pb}$ ) of such melts will still accurately reflect that of the source, thus enforcing the paradox that OIB and MORB mantles have markedly higher $\mathrm{Ce} / \mathrm{Pb}$ (and $\mathrm{Nd} / \mathrm{Pb}$ ) than the bulk silicate earth. This implies large deficiencies of $\mathrm{Pb}$ in the mantle sources for these basalts. Sulfide may play other important roles during magmagenesis: 1). advective/diffusive sulfide networks may form potent metasomatic agents (in both introducing and obliterating $\mathrm{Pb}$ isotopic heterogeneities in the mantle); 2). silicate melt networks may easily exchange $\mathrm{Pb}$ with ambient mantle sulfides (by diffusion or assimilation), thus 'sampling' $\mathrm{Pb}$ in isotopically heterogeneous mantle domains differently from the silicate-controlled isotope tracer systems ( $\mathrm{Sr}, \mathrm{Nd}, \mathrm{Hf}$ ), with an apparent 'de-coupling' of these systems.
\end{abstract}

\section{INTRODUCTION}

The geochemical behavior of $\mathrm{Pb}$ in the earth is replete with enigmas and paradoxes. There is as yet no satisfactory "balanced budget" for $\mathrm{Pb}$ amongst the various terrestrial reservoirs, and consequently, no consensus understanding of the $\mathrm{U}-\mathrm{Th}-\mathrm{Pb}$ isotope tracer system, or the behavior of $\mathrm{Pb}$ during mantle melting processes. Virtually all oceanic mantle melts have $\mathrm{Pb}$ isotopic compositions that are more radiogenic than Earth's 
Geochron, and all have high and relatively constant $\mathrm{Ce} / \mathrm{Pb}$ ratios $(\sim 25)$ compared to "bulk silicate earth" $(\sim 11)$. Yet experimentally determined silicate mineral/melt partition coefficients for $\mathrm{Ce}$ and $\mathrm{Pb}$ differ significantly, so that significant fractionations in $\mathrm{Ce} / \mathrm{Pb}$ should abound between various mantle reservoirs and various melting regimes.

We contend that major new understandings of mantle $\mathrm{Pb}$ geochemistry can be achieved by noting that, because $\mathrm{Pb}$ is chalcophilic, its behavior will be strongly controlled by sulfide phases during melting and differentiation processes, as well as possible large scale sequestering of sulfide into the deep mantle or core during lithospheric plate recycling. Unfortunately, there is at present only sparse experimental data relevant to the partitioning or diffusive exchange rates of $\mathrm{Pb}$ between sulfide phases and silicate phases. Nevertheless, a self-consistent picture of the role of sulfide in controlling the geochemical behavior of $\mathrm{Pb}$ in the mantle can be drawn in anticipation of future experimental results.

\section{BACKGROUND}

The classical $\mathrm{Pb}$ isotope paradox, long-standing for many decades, arises from the fact that most of the known mantle reservoirs have $\mathrm{Pb}$ isotope compositions that are more radiogenic than the bulk earth "Geochron", Figure 1. By definition, the bulk earth should lie on a 4.53 g.y. single-stage isochron, thus there must exist somewhere a terrestrial reservoir that has sufficient un-radiogenic $\mathrm{Pb}$ to balance the observed radiogenic reservoirs. Traditional solutions to this paradox involve storage of the missing $\mathrm{Pb}$ in either the earth's core (Oversby and Ringwood 1971; Vollmer 1977; Vidal and Dosso 1978; Sun 1980; Allegre et al. 1980, 1982; Allegre 1982), or in the lower continental crust (Zartman and Haines 1988; O'Nions et al. 1979; note that the upper continental crust is highly radiogenic). Recently, Godard et al. (2005) proposed that low $\mathrm{Ce} / \mathrm{Pb}$ ratios are ubiquitous in upper mantle ocean ridge peridotites, and over time this excess $\mathrm{Pb}$ may be sequestered and "hidden" in the deep mantle.

With the discovery, based on ${ }^{182} \mathrm{Hf}^{182} \mathrm{~W}$, that earth's core formed within $30-50$ my of accretion (Klein et al. 2002; Klein et al. 2004; Jacobsen 2003), the location of the Geochron is well constrained (shown in Fig. 1 at 4.534 g.y.); thus the Pb paradox cannot be easily resolved by early sequestering of $\mathrm{Pb}$ during core in-fall. We suggest that continuing interaction between silicate mantle and an early formed core does allow for long-term extraction of $\mathrm{Pb}$ into the core.

With respect to the continental crust, most estimates now argue for a total crust close to the Geochron $\left({ }^{238} \mathrm{U} /{ }^{204} \mathrm{~Pb} \sim 8.4\right.$, McColloch and Bennett 1994), or mildly to the unradiogenic side $\left({ }^{238} \mathrm{U} /{ }^{204} \mathrm{~Pb} \sim 5.7\right.$, Zindler and Hart 1986; 6.9, Rudnick and Fountain 1995; 4.5, Gao et al. 1998). Whether the $\mathrm{Pb}$ content in this crust is sufficient to balance the strongly radiogenic oceanic mantle reservoirs (MORB plus OIB) cannot be determined, as neither the $\mathrm{Pb}$ concentrations nor the masses of the OIB mantle reservoirs are known.

In addition to this Classical $\mathrm{Pb}$ Paradox, there is what might be called the Third $\mathrm{Pb}$ Paradox (The Second Pb Paradox relates to the Th-U-Pb systematics of the MORB mantle; see Hofmann 2003). Hofmann et al. (1986) posited that $\mathrm{Pb}$ and $\mathrm{Ce}$ behave 
similarly (have similar silicate mineral/melt partition coefficients) during melting of the mantle sources of both OIB (ocean island basalts) and MORB (mid-ocean ridge basalts). This view was challenged by Sims and DePaolo (1997), who argued that $\mathrm{Ce} / \mathrm{Pb}$ fractionations are common in sub-sets of global data, and that the "canonical" global $\mathrm{Ce} / \mathrm{Pb}$ ratio is in fact quite sensitive to details of the melting process. They showed that $\mathrm{Pb}$ is generally more compatible than $\mathrm{Ce}$, and suggested a role for sulfide in controlling the partitioning of $\mathrm{Pb}$.

More recently, Hofmann (2003) has argued that Nd is a slightly better surrogate for $\mathrm{Pb}$ than is $\mathrm{Ce}$ (we will adopt the $\mathrm{Nd}-\mathrm{Pb}$ pair here, as there is more high quality paired $\mathrm{Nd}-$ $\mathrm{Pb}$ data in the literature for peridotites, to be discussed below). $\mathrm{The} \mathrm{Nd} / \mathrm{Pb}$ ratio of OIB averages $\sim 15$ over a wide range of Nd concentrations, Figure 2; average N-MORB is slightly higher, $\sim 23$. These values are significantly higher than values derived for the bulk silicate earth $(\mathrm{Nd} / \mathrm{Pb} \sim 8.3$ (McDonough and Sun 1995; hereafter M\&S95). Nd/Pb appears strongly fractionated during continental crust formation $(\mathrm{Nd} / \mathrm{Pb} \sim 1.6-3.6$; McCulloch and Bennett 1994; Rudnick and Fountain 1995; Gao et al. 1998). One conclusion has been that non-magmatic processes are involved in crust formation, and that these are able to strongly fractionate $\mathrm{Nd} / \mathrm{Pb}$ (Peucker-Ehrenbrink et al. 1994). It is generally assumed that long-term extraction of continental crust is the main reason the MORB mantle (DMM) is depleted; to first order, the continental crust and depleted upper mantle $\mathrm{Nd}$ and $\mathrm{Pb}$ budgets do in fact sum back to the bulk earth value (Workman and Hart 2005). What reservoir then can be used to balance the OIB mantle, and why do the MORB and OIB mantles appear today to both have high $\mathrm{Nd} / \mathrm{Pb}$ ratios?

To illuminate this question, Figure 3 shows trace element patterns for the known "end-member" mantle reservoirs (DMM, EM1, EM2, HIMU; Zindler and Hart 1986), in the form of bulk-earth-normalized "spidergrams". In all cases, these patterns show consistent negative anomalies for $\mathrm{Pb}$ concentrations, and $\mathrm{Ce} / \mathrm{Pb}$ ratios similar to Hofmann's canonical value of $25(24.1,20.5 \pm 0.4,20.9 \pm 1.4$ and $32.1 \pm 2.0$ for N-MORB, EM1, EM2, HIMU respectively; $2 \sigma$ standard errors). Is it possible that the apparent negative $\mathrm{Pb}$ anomaly is simply due to an erroneous "normalizing" factor for bulk silicate earth? Because $\mathrm{Pb}$ is not a refractory element, its abundance in the bulk earth cannot be determined directly by comparison with meteorite abundances of refractory elements. While $\mathrm{Pb}$ contents are reasonably well-behaved in terrestrial peridotites (Tatsumoto et al. 1992; Meijer et al. 1990), no one has attempted to derive bulk earth $\mathrm{Pb}$ abundances using the approach of Jagoutz et al (1979) and Hart and Zindler (1986). Instead, the conventional approach is to use $\mathrm{Pb}$ isotopes to define the ${ }^{238} \mathrm{U} /{ }^{204} \mathrm{~Pb}$ ratio $(\mu)$ of the mantle, and then to deduce the $\mathrm{Pb}$ content from the bulk earth abundance of $\mathrm{U}, \mathrm{a}$ refractory element well-modeled using a chondritic analogue. MORB and OIB lie approximately along a secondary ${ }^{207} \mathrm{~Pb} /{ }^{204} \mathrm{~Pb}-{ }^{206} \mathrm{~Pb} /{ }^{204} \mathrm{~Pb}$ isochron, Fig. 1, that constrains $\mu$ to be $\sim 8.25$ for the oceanic mantle (for comparison, continental upper crustal rocks define a growth curve with $\mu \sim 9.7$; Stacey and Kramers 1975). Accepting a "chondritederived" $U$ concentration in the bulk silicate earth of $20.8 \mathrm{ppb}$ (Hart and Zindler 1986), and a $\mu$ of 8.25 , leads to a $\mathrm{Pb}$ concentration in the BSE of $157 \mathrm{ppb}$; this compares well with the value of $150 \mathrm{ppb}$ derived in a similar way by M\&S95. Coupling $157 \mathrm{ppb} \mathrm{Pb}$ with $\mathrm{Ce}$ and $\mathrm{Nd}$ abundances of 1.675 and $1.25 \mathrm{ppm}$ (M\&S95, derived from refractory element abundances in chondrites) leads to a bulk earth $\mathrm{Ce} / \mathrm{Pb}$ of $\sim 10.7$, and $\mathrm{Nd} / \mathrm{Pb}$ of $\sim 8.0$. We 
believe this approach is robust, and leads to the conclusion that either all mantle sampled by MORB and OIB has been depleted in $\mathrm{Pb}$, relative to the REE, or that the partitioning of $\mathrm{Ce}$ (or $\mathrm{Nd}$ ) and $\mathrm{Pb}$ are in fact not similar during mantle melting, so that $\mathrm{Ce} / \mathrm{Pb}$ in MORB and OIB do not reflect that of their mantle source.

Existing experimental data involving the major mantle silicate phases suggest that $\mathrm{Ce}$ (or $\mathrm{Nd}$ ) and $\mathrm{Pb}$ may not have similar partition coefficients, though not all of the data is consistent. Four experimental studies of $\mathrm{Pb}$ and REE partitioning between $\mathrm{cpx}$, garnet and silicate melt show $\mathrm{D}_{\mathrm{Ce}} / \mathrm{D}_{\mathrm{Pb}}$ values ranging from 3-10 for cpx, and from 3-500 for garnet (Hauri et al. 1994; Lundstrom et al. 1998; Salters et al. 2002; Schmidt et al. 1999). In contrast, data from Klemme et al. (2002) and Keshav et al. (2005) show lower $\mathrm{D}_{\mathrm{Ce}} / \mathrm{D}_{\mathrm{Pb}}$ values for cpx (0.5-0.8), due to much larger $\mathrm{Pb}$ partition coefficients. The higher $\mathrm{D}_{\mathrm{Ce}} / \mathrm{D}_{\mathrm{Pb}}$ values are clearly inconsistent with the Hofmann et al. (1986) proposal that $\mathrm{Ce}$ and $\mathrm{Pb}$ have similar partition coefficients during mantle melting, at least if $\mathrm{Ce}$ and $\mathrm{Pb}$ partitioning are controlled simply by silicate phases. As noted in the Introduction, we feel that the influence of sulfide phases on $\mathrm{Pb}$ partitioning is a key missing piece of these puzzles.

\section{BEHAVIOR OF SULFIDE DURING MELTING OF THE MANTLE}

Here we review what is known about the abundance of sulfide in the mantle, its phase equilibria, physical properties and the kinetics of cation transport in sulfide solids and melts.

\section{IIIA. Mantle Sulfide Abundances and Petrology}

The $\mathrm{S}$ content of the bulk silicate earth (BSE) is about $250 \mathrm{ppm}(\mathrm{M} \& \mathrm{~S} 95)$, though it is difficult to establish this directly from mantle peridotites due to weathering and metasomatic alteration issues (Lorand 1991; Lorand et al. 2003; Ionov et al. 1992). Mantle sulfur is largely present as sulfide (Moretti and Ottonello 2005; Jugo et al. 2005). For typical mantle sulfides with $\sim 38 \mathrm{wt} . \% \mathrm{~S}, 250 \mathrm{ppm} \mathrm{S}$ in the mantle translates into $0.066 \%$ sulfide (virtually no sulfur is budgeted in mantle silicate minerals; Eggler and Lorand 1993 estimate that at least $95 \%$ of the sulfur in primitive mantle will be present in mono-sulfide solid solution, Mss). Even for the upper mantle, that has undergone continuous depletion over the past several billion years by $2-3 \%$ melt extraction (Workman and Hart 2005), sulfur will be only mildly depleted ( 10-15\%), since the S contents of the basalts extracted to create the depletion are relatively low (1000-1500 ppm). Bézos et al. (2005) estimate the $\mathrm{S}$ content of the MORB mantle at $190 \pm 40 \mathrm{ppm}$. Thus the residual mantle sulfide content will still be $\sim 0.05 \%$; during present-day upper mantle MORB melting, sulfide should remain as a residual phase up to $15 \%$ total melting (Bézos et al. 2005), and will certainly be a residual phase in lower-degree OIB melts from more fertile mantle.

The mantle sulfide assemblage, as observed sub-solidus in peridotite xenoliths and massifs, is typically a combination of pyrrhotite $\left(\mathrm{Fe}_{1-\mathrm{X}} \mathrm{S}\right)$, pentlandite $\left((\mathrm{Fe}, \mathrm{Ni})_{9} \mathrm{~S}_{8}\right)$ and chalcopyrite $\left(\mathrm{CuFeS}_{2}\right)$ (Garuti et al. 1984; Szabo and Bodnar 1995). Near the sulfide solidus, there is extensive solid solution between ternary ( $\mathrm{Fe}, \mathrm{Ni}, \mathrm{Cu}) \mathrm{S}$ mono-sulfide compositions, and for expected Fe-Ni-Cu compositions only a single Mss phase is likely. 
Melting is divariant for these Mss, ultimately becoming (above the liquidus) a singlephase sulfide liquid that is highly immiscible in silicate melts (the partitioning of $\mathrm{S}$ between these immiscible melts is of order 350). Sulfide melts are unquenchable in nature (and only with great difficulty in the lab).

Figure 4 shows a P-T phase diagram for the melting relationships of a particular Mss composition, chosen to be appropriate for equilibrium with mantle peridotite (adapted from Bockrath et al. 2004). What stands out here is the low temperature of the sulfide solidus, and the large two-phase solid + liquid sulfide field. Note that the highly-curved sulfide liquidus as drawn by Bockrath et al. (2004) is not well constrained at high temperature, and is in fact inconsistent with the congruent melting temperature of pure FeS (shown on the figure). The univariant melting of troilite should set an upper limit for the polyvariant melting of Mss (i.e. the addition of $\mathrm{Ni}, \mathrm{Cu}, \mathrm{Fe}, \mathrm{S}$, etc, to $\mathrm{FeS}$ will lower the melting point; Li et al. 1996; Ebel and Naldrett 1996). Given this, it would appear that Mss should be completely molten well before the silicate portion of the peridotite starts to melt. For a reasonable mantle potential temperature $\left(1500^{\circ} \mathrm{C}\right)$, mantle upwelling along an adiabat will intersect the sulfide solidus at $\sim 160 \mathrm{~km}$ depth, and the sulfide will be fully molten before the upwelling even reaches the peridotite solidus at $\sim 110 \mathrm{~km}$. As discussed below, this will be important to the issue of possible migration or settling of sulfide melt in subsolidus peridotite.

\section{IIIB. Pb Partitioning Between Sulfides and Silicates}

There is very little data (at mantle $\mathrm{P} \& \mathrm{~T}$ ) relevant to the partitioning of $\mathrm{Pb}$ between the silicate and sulfide phases of interest here (this is in stark contrast to the wealth of data on sulfide-silicate partitioning of PGEs (Barnes et al. 2004; Bockrath et al. 2004; Fleet et al. 1991; Fleet et al. 1996; Li et al. 1996; Peach et al. 1994; Sattari et al. 2002)). Oversby and Ringwood (1971) reported $\mathrm{Pb}$ partition coefficients of 9.8 and 12.4 between sulfide and basaltic melts. However, their sulfide melts were cation-rich compared to likely mantle sulfide compositions (molar Fe/S 1.3, compared to the molar $(\mathrm{Fe}+\mathrm{Ni}+\mathrm{Cu}) / \mathrm{S}$ ratio of 0.93 adopted by Bockrath et al. 2004). Shimizaki and MacLean (1976) reported $\mathrm{Pb}$ partitioning between oxygen-rich $\mathrm{Fe}-\mathrm{Pb}$ sulfide liquids and a compositionally simple $\mathrm{SiO}_{2}-\mathrm{Na}_{2} \mathrm{O}-\mathrm{FeO}$ silicate melt $(\sim 34 \% \mathrm{Fe})$. The sulfide/silicate $\mathrm{K}_{\mathrm{d}}$ for $\mathrm{Pb}$ ranged from $1.6-$ 9.3, and increased strongly as oxygen in the sulfide melt decreased (their lowest oxygen value was $\sim 6 \%$ ). Although their compositions are wildly unlike those relevant to mantle peridotite melting, their results, along with the Oversby and Ringwood data, predict compatible behavior for $\mathrm{Pb}$ in sulfide melts. Recently, Brenan and McDonough (2005) reported $\mathrm{Pb}$ partition coefficients of 10-40 between FeS melt and basalt melt. Gaetani and Grove $(1997,1999)$ showed that $\mathrm{Co}, \mathrm{Cu}$ and $\mathrm{Ni}$ were highly compatible in sulfide melts, relative to olivine; while they did not determine values for $\mathrm{Pb}$, they discussed the effect that sulfide might have on $\mathrm{U} / \mathrm{Pb}$ and $\mathrm{Th} / \mathrm{Pb}$ fractionations in mantle peridotite, and estimated a sulfide/olivine partition coefficient for $\mathrm{Pb}$ of 2000 .

An indirect "natural" estimate of $\mathrm{Pb}$ partitioning can be derived from analyses of natural peridotites and assumed "complementary" melts. Meijer et al. (1990), in a classic study, analyzed $\mathrm{Pb}$ (and a few other trace elements, all by isotope dilution) in leached highly pure silicate mineral separates from a peridotite. They then reconstructed a clean "whole rock" composition using known mineral modes. This circumvented the proverbial 
problems of alteration and contamination that affect such elements $\mathrm{as} \mathrm{Rb}, \mathrm{U}$ and $\mathrm{Pb}$ in peridotite. The reconstructed $\mathrm{Pb}$ content was $3.3 \mathrm{ppb}$ ( Th, U, Nd, $\mathrm{Sr}$ and $\mathrm{Sm}$ were also reconstructed). Based on this partial "spidergram", shown in Figure 5, the "whole rock" $\mathrm{Pb}$ can be estimated at $\sim 25-35 \mathrm{ppb}$. Thus the silicate minerals account for only $\sim 9-13 \%$ of the $\mathrm{Pb}$ expected in the peridotite (based on the neighboring spidergram elements), and Meijer et al. (1990) postulated that the rest of the Pb was sequestered in sulfide. This supposition is supported by a comparison of the reconstructed whole rock of Meijer et al. (1990) with the estimate of depleted upper mantle (DMM) composition derived by Workman and Hart (2005) - see Fig. 5. Also shown in Fig. 5 is the average of 4 spinel and 2 garnet lherzolites analyzed by Tatsumoto et al. (1992), showing only a minimal negative $\mathrm{Pb}$ anomaly in these "whole rocks". Other studies of natural peridotite xenoliths show similar minimal $\mathrm{Pb}$ anomalies in whole rocks versus "missing $\mathrm{Pb}$ " in the silicate phases (Carignan et al. 1996; Ionov et al. 2006).

The peridotite studied by Meijer et al. (1990) had Nd isotopic ratios similar to that of MORB mantle; we earlier estimated the modal sulfide content of MORB mantle to be $0.05 \%$. The $\mathrm{Pb}$ content of this sulfide would then be $\sim 75 \mathrm{ppm}$. From a hypothetical primary MORB (with $0.4 \mathrm{ppm} \mathrm{Pb;} \mathrm{Workman} \mathrm{and} \mathrm{Hart,} \mathrm{2005)} \mathrm{that} \mathrm{might} \mathrm{have} \mathrm{been} \mathrm{in}$ equilibrium with this sulfide, a sulfide/silicate melt partition coefficient of $\sim 200$ can be calculated. With respect to the $\mathrm{Ce} / \mathrm{Pb}$ paradox, a partition coefficient of only $20-25$ (sulfide melt/silicate melt) would produce a "bulk $\mathrm{Kd}$ " for $\mathrm{Pb}$ during peridotite melting that is equal to the bulk silicate $\mathrm{Kd}$ for Ce! While these values are, at best, loosely constrained, it is hard to escape the conclusion that $\mathrm{Pb}$, as a chalcophile element, prefers sulfide to silicate melt, and that sulfide will exert a major control on $\mathrm{Pb}$ during peridotite melting.

There is one reconnaissance study of $\mathrm{Pb}$ partitioning between troilite (stoichiometric $\mathrm{FeS}, \sim 1 \% \mathrm{Ni}$ ) and Fe-Ni sulfide melt (Jones et al. 1993), indicating a troilite/sulfide melt $\mathrm{K}_{\mathrm{d}}$ of $\sim 0.005$. This suggests $\mathrm{Pb}$ will be strongly incompatible in solid mono-sulfide (mss) phases, relative to sulfide melts, so that strong fractionations of $\mathrm{Pb}$ can be expected not just between sulfide and silicate, but also between solid and molten sulfide. This is in strong contrast with the partitioning behavior of other chalcophile elements between Mss and melt; for example, mss/melt $\mathrm{K}_{\mathrm{d}}$ 's are $\sim 0.25$ for $\mathrm{Cu}, \sim 0.20$ for $\mathrm{Pd}$ and $\sim 5$ for $\mathrm{Rh}$ (Barnes et al. 1996).

\section{IIIC. Sulfide Saturation of Silicate Melt}

The nature of sulfide saturation is important because it determines whether an ascending silicate melt will tend to exsolve or digest sulfide. The first-order observation is that the solubility of sulfide in silicate melts increases with decreasing pressure, thus an adiabatic ascending magma, interacting with sulfide-bearing mantle, will tend to assimilate sulfide (and its $\mathrm{Pb}, \mathrm{PGEs}$, etc.). This is likely to be a very important process in controlling both the geochemical behavior of $\mathrm{Pb}$, and its isotopic composition. It has been implicated previously as a significant facet of Os geochemistry in MORBs and OIBs (Hart and Ravizza 1996). To evaluate this in more detail, Figure 6 shows the sulfur content of basalt saturated with molten sulfide (as FeS), as a function of $\mathrm{P}$ and $\mathrm{T}$ (using the parameterization of Mavrogenes and O’Neill 1999). For ascent along a basalt adiabat, under-saturation is strong and continuously increasing, and sulfide assimilation should be 
the rule. However, most melts will not ascend adiabatically, as the melting process is endothermic and $\mathrm{S}$ saturation decreases with decreasing temperature. Figure 6 also shows a curve for sulfide saturation along the peridotite solidus, which sets a lower limit to the sulfur content of near-solidus melts. The actual P-T path followed by residual peridotite during continuous melt extraction (Asimow et al. 1995; Asimow et al. 2004), which represents the conditions most realistic for ascending melt, lies closer to the melt adiabat than the solidus, and still tends strongly toward under-saturation during upwelling, Figure 6. Erupted MORB and OIB melts are frequently saturated with sulfide, as evidenced by the presence of immiscible sulfide blebs in basaltic glasses. We have not attempted to back-track melts along their "liquid-line-of-descent" to ascertain whether primary melts in the upper mantle are sulfide-saturated, prior to conductive cooling and differentiation in shallow magma chambers.

Thus both the sulfide dissolution rate and the diffusive exchange rate for $\mathrm{Pb}$ will be key parameters in understanding how this sulfide-saturation process controls $\mathrm{Pb}$ abundances in silicate melts, and how this may relate to the $\mathrm{Ce} / \mathrm{Pb}$ paradox and to the possible de-coupling of $\mathrm{Pb}$ isotopes from $\mathrm{Sr}, \mathrm{Nd}$ and $\mathrm{Hf}$ isotopes during interaction of magmas with mantle sulfides.

\section{IIID. Transport of Pb by diffusion through sulfides}

Given the evidence that sulfide will be a residual phase in mantle peridotites during melting, it is important to know how rapidly $\mathrm{Pb}$ in transiting silicate melts will reequilibrate with these sulfides. While there is as yet no diffusion data for $\mathrm{Pb}$ in either silicate or sulfide phases, there is data for $\mathrm{Fe}$ and Os that suggests very rapid diffusion rates in mono-sulfide phases. Self-diffusion of $\mathrm{Fe}$ in pyrrhotite $\left(\mathrm{Fe}_{1-\mathrm{x}} \mathrm{S}\right)$ at $1400{ }^{\circ} \mathrm{C}$ is $5 \times 10^{-6} \mathrm{~cm}^{2} / \mathrm{s}$; in FeS melt, $\mathrm{Fe}$ is $>100$ times faster (Condit et al. 1974; Yang et al. 1959). For contrast, $\mathrm{Fe}^{2+}$ diffusion in basaltic melt is $\sim 10 \mathrm{x}$ slower than $\mathrm{Fe}$ in pyrrhotite! Os diffusion in pyrrhotite at $1400{ }^{\circ} \mathrm{C}$ is $3 \times 10^{-8} \mathrm{~cm}^{2} / \mathrm{s}$, more than 100 times slower than $\mathrm{Fe}$, but still impressively rapid (Brenan et al. 2000). For example, if $\mathrm{Pb}$ and Os diffusivities are similar, grain-scale equilibration of $\mathrm{Pb}$ in $\mathrm{mm}$ sulfides at $1400^{\circ} \mathrm{C}$ would occur on time-scales of days. Scant work has been done on pressure effects on diffusion, though Dobson (2000) showed that Fe diffuses 8 times slower in a Fe-FeS eutectic melt at $5 \mathrm{GPa}$ compared to $2.2 \mathrm{GPa}$.

\section{IIIE. Transport of Pb by advection of sulfide melt}

At textural equilibrium, the distribution and connectivity of a small amount of melt in a polycrystalline aggregate depends upon the characteristic dihedral, or wetting, angle $(\theta)$ that forms where two contacting solid grains bound a pocket of melt. For large values of $\theta$, a small amount of melt will form isolated pockets at four grain junctions if the surface energy of the solid is isotropic. Decreasing $\theta$ increases the tendency for melt to wet threegrain junctions until, at $\theta=60^{\circ}$ or less, an interconnected network will form even for very small amounts of melt (e.g., Smith 1964; von Bargen and Waff 1986). Several studies show that the dihedral angle between sulfide melt and olivine decreases strongly as the oxygen and sulfur content of the sulfide melt increases (Minarik et al. 1996; Gaetani and Grove 1999; Rose and Brenan 2001; Terasaki et al. 2005). The wetting angle is also mildly dependent on the $\mathrm{Ni}, \mathrm{Cu}$, Co content of the melt (Rose and Brenan 2001). 
Although the oxygen content of molten sulfide is not well constrained at upper mantle conditions, existing experimental data suggest that it increases monotonically at $\mathrm{f}_{\mathrm{O} 2}$ 's approaching the fayalite-magnetite-quartz buffer, for $\mathrm{Fe}-\mathrm{Ni}-\mathrm{Cu}$ sulfide melt with anion/cation ratios greater than 1 (Fig. 7). This is the type of sulfide thought to be present in the upper mantle (e.g., Bockrath et al. 2004), and the transition from non-wetting to wetting (i.e. $\theta=60^{\circ}$ ) for these melts with respect to olivine occurs when the concentration of $\mathrm{O}$ exceeds $\sim 2$ to $6 \mathrm{wt} \%$ to pressures of at least $3.9 \mathrm{GPa}$ (Fig. 7).

This indicates that molten sulfide is likely to wet olivine, forming interconnected networks throughout at least the upper $\sim 120 \mathrm{~km}$ of the mantle. However, it should be noted that Terasaki et al. (2005) conducted experiments to determine the dihedral angle between anion-rich sulfide and olivine at 4.6 to $8.0 \mathrm{GPa}$ and concluded that $\theta$ does not decrease below $60^{\circ}$ for oxygen contents similar to those shown in Fig. 7 at these conditions. While this pressure effect is not evident in the data of Minarik et al. (1996), it raises the possibility that there is a pressure between 3.9 and $4.6 \mathrm{GPa}$ where sulfide converts from wetting to non-wetting with respect to olivine. Although several other high-pressure studies conclude that molten sulfide does not wet mantle olivine, it should be noted that all of these experiments were on starting compositions on the Fe-rich side of $\mathrm{FeS}$ (i.e. they are anion poor), and are unlikely to be suitable analogues for natural upper mantle sulfides (e.g., Balhaus and Ellis, 1996). Urakawa et al. (1987) did show that $\mathrm{O}$ in such Fe-rich sulfide melts increased with pressure (from $6 \mathrm{GPa}$ to $15 \mathrm{GPa}$ ), and that sulfide melt was wetting against $\mathrm{MgO}$ in an experiment at $2500^{\circ} \mathrm{C}$ and $6 \mathrm{GPa}$. And Yoshino et al. (2004), from electrical conductivity experiments, found that even highlyreduced $\mathrm{Fe}-\mathrm{FeS}$ eutectic melts in peridotite appeared to inter-connect at melt fractions above $5 \%$.

Until further experiments are done on anion-rich $\mathrm{Fe}-\mathrm{Ni}-\mathrm{Cu}-\mathrm{S}$ compositions under well-controlled $\mathrm{f}_{\mathrm{O} 2}$ and $\mathrm{f}_{\mathrm{S} 2}$ conditions, the connectivity of small-degree sulfide melts in upper mantle peridotite must be viewed as an open question. And as yet, there are no experiments at lower mantle pressures in perovskite-facies silicate assemblages. In any event, once upper mantle silicate melting begins, the sulfide melt will become globular, and inter-granular flow will be greatly inhibited (Mungall and $\mathrm{Su} 2005$ ); entrainment and flow of sulfide in silicate melt may be possible in larger channels, as the sulfide droplets will tend to remain small and not aggregate (de Bremond d'Ars et al. 2001). As mentioned above, there is a large depth interval between the sulfide solidus and the silicate solidus ( $>50 \mathrm{~km}$, Fig. 4), so the potential for large-scale sulfide-induced " $\mathrm{Pb}$ metasomatism" is noteworthy (Gaetani and Grove 1999).

The efficiency of such a metasomatic transport process is obviously dependent on the viscosity of sulfide melt; Dobson et al. (2000) showed that the viscosity of pure FeS melt was approximately homologous with the melting temperature of $\mathrm{FeS}$, and averaged $\sim 10^{-2}$ $\mathrm{Pa}-\mathrm{S}$ for P-T conditions deeper than the silicate solidus. For context, this is several orders of magnitude less viscous than basaltic melt at a similar P \& T (and only 10 times more viscous than water at $\mathrm{STP}$ ). The effects of $\mathrm{Ni}, \mathrm{Cu}, \mathrm{f}_{\mathrm{S} 2}$ and $\mathrm{f}_{\mathrm{O} 2}$ on viscosity are not known, but orders-of-magnitude changes are unlikely. 


\section{IIIF. The Third Pb Paradox}

Hofmann et al. (1986) introduced an elegant method for determining the relative incompatibilities of elements during melting of the mantle. They argued that when the ratio of two elements does not change over a wide range of element concentration, those elements can be inferred to have the same partition coefficients, and, as a corollary, the "canonical" ratio given by the melts directly provides the ratio of the mantle source. As discussed in the Introduction, this leads to the Third Pb Paradox, where one of these canonical ratios $(\mathrm{Ce} / \mathrm{Pb}$ or $\mathrm{Nd} / \mathrm{Pb})$ for virtually all oceanic mantle is distinctly different from the well-established "bulk silicate earth" values. We have argued here that sulfide is an important phase that controls $\mathrm{Pb}$ abundances during melting. Here we explore whether this helps to resolve the Third Pb Paradox.

Fig. 8 details a variety of melting models that explicitly invoke partitioning of $\mathrm{Pb}$ into residual sulfide. For simplicity, these models start with bulk earth contents of $\mathrm{Nd}$ and $\mathrm{Pb}$ (note that this is not an attempt to directly model the oceanic basalt data shown in Fig. 2). The relevant partition coefficients and melting parameters are given in Table 1. Three models are compared: simple aggregated fractional modal melting of either spinel or garnet peridotite, and a more realistic aggregated fractional non-modal melting of garnet peridotite followed by spinel peridotite. In all three cases, a reasonable sulfide/silicate $\mathrm{K}_{\mathrm{d}}$ for $\mathrm{Pb}$ can be chosen that generates relatively constant $\mathrm{Nd} / \mathrm{Pb}$ over a wide range of $\mathrm{Nd}$ concentrations; in other words, these models easily produce the "canonical" $\mathrm{Nd} / \mathrm{Pb}$ ratios of the Hofmann et al. (1986) type, despite the fact that silicate mineral/melt partition coefficients for $\mathrm{Nd}$ and $\mathrm{Pb}$ are not equal. $\mathrm{Pb}$ in the modal sulfide phase essentially "adds" to the silicate $\mathrm{K}_{\mathrm{d}}$ for $\mathrm{Pb}$ to bring the "bulk" partition coefficients of $\mathrm{Pb}$ into equality with Nd. The lower panel of Fig. 8 shows the sensitivity of the melt trajectories to the choice of sulfide/silicate $K_{d}$. While the slope of the trajectories is very sensitive to $K_{d}$, the variability of $\mathrm{Nd} / \mathrm{Pb}$ is still not large compared to the typical scatter of actual basalt data on a Hofmann plot, such as Fig. 2, for the range of partition coefficients explored here (note that such plots typically utilize log scaling for the Y-axis!).

A more important result of this modeling is the convergence of melt trajectories toward the initial mantle $\mathrm{Nd} / \mathrm{Pb}$ ratio, as $\mathrm{Nd}$ content decreases. It is apparently difficult, even with residual sulfide in a melting regime, to derive melts that differ significantly from their source in $\mathrm{Nd} / \mathrm{Pb}$ (or $\mathrm{Ce} / \mathrm{Pb}$ ). Additionally, it is possible to produce a horizontal trajectory for elements more incompatible than $\mathrm{Nd}$ by simply choosing a lower sulfide/silicate $\mathrm{K}_{\mathrm{d}}$. For example, an almost invariant $\mathrm{Ce} / \mathrm{Pb}$ ratio can be derived with this model by using a sulfide/silicate $\mathrm{K}_{\mathrm{d}}$ of 14 . Thus it appears that the presence of residual sulfide in the upper mantle can explain constant $\mathrm{Nd} / \mathrm{Pb}$ (or $\mathrm{Ce} / \mathrm{Pb}$ ) and that the Third $\mathrm{Pb}$ Paradox is alive and well, with the known oceanic mantle end-members having $\mathrm{Ce} / \mathrm{Pb}$ and $\mathrm{Nd} / \mathrm{Pb}$ ratios higher than "bulk earth" values. This implies that the ubiquitous negative $\mathrm{Pb}$ anomalies seen on spidergrams such as Fig. 3 do in fact reflect their mantle source, and are not dominantly caused by retention of $\mathrm{Pb}$ in residual mantle sulfide. However, given the discussion above regarding the tendency for sulfide melt to move around, or interact with melts by resorption/crystallization or diffusion, the modeling presented here must still be regarded as an oversimplification, as it does not include these various melt-rock reaction processes. Experimental measurement of sulfide/silicate $\mathrm{K}_{\mathrm{d}}$ for $\mathrm{Pb}$ is necessary, but is only a first step toward understanding this fairly complex system. 


\section{SPECUlations AND CONJECTURES}

The $\mathrm{Ce} / \mathrm{Pb}$ paradox persists, as melting in the presence of residual sulfide reliably constrains the mantle source $\mathrm{Ce} / \mathrm{Pb}$, over a broad range of sulfide/silicate $\mathrm{K}_{\mathrm{d}}$ for $\mathrm{Pb}$ (though this partitioning is as yet poorly known). Observed $\mathrm{Ce} / \mathrm{Pb}$ (and $\mathrm{Nd} / \mathrm{Pb}$ ) ratios for OIB and MORB mantles are indeed greater than bulk earth values, and a complementary reservoir (the continental crust?) is still needed.

The presence of a low viscosity sulfide melt in sub-solidus peridotite may lead to a variety of mantle metasomatic processes, and paradoxical behavior of $\mathrm{Pb}$. Being denser than silicate (Fe-Ni-Cu-S melts lie in the range 4.0-5.5 g/ $\mathrm{cm}^{3}$; Mungall and $\mathrm{Su} 2005$ ), sulfide melts may lag solid mantle upwelling, creating a form of zone-refining; sulfide melts may tend to aggregate or pond at depth near the sulfide solidus, stripping $\mathrm{Pb}$ from silicate phases during peridotite upwelling.

Relatively large-scale transport of $\mathrm{Pb}$ across heterogeneous mantle domains may be the rule, given the possibility of interconnected sulfide melt in sub-solidus peridotite, the negative buoyancy-driven advection of this melt, and the possibility of high diffusion rates of $\mathrm{Pb}$ in a standing sulfide melt network. For example, if the mantle is composed of both mafic and peridotitic lithologies, the sulfide network may augment isotopic equilibration of $\mathrm{Pb}$ across these domains, while lithophile isotopes ( $\mathrm{Sr}, \mathrm{Nd}, \mathrm{Hf}$ ) may be relatively immobile. This would lead to de-coupling of $\mathrm{Pb}$ isotopes from the other isotope systems.

At depths above the peridotite solidus, transiting silicate melts will probably be under-saturated in sulfide, thus both assimilation of sulfide (and its $\mathrm{Pb}$ ), and diffusive exchange of $\mathrm{Pb}$ will be prevalent. This will again produce de-coupling of $\mathrm{Pb}$ from the lithophile isotopes (not to mention its affect on trace element patterns). For example, it is hard to escape the notion that plume-derived melts, during ascent through a MORB-type lithosphere, will tend to assimilate or equilibrate with sulfides containing $\mathrm{Pb}$ with MORB-type isotopic compositions. This may also be true for Os isotopes; given the strongly chalcophilic character of Os, much of what we have conjectured above may also apply to Os, and the voluminous literature on this isotope system should be re-examined for such evidence.

We hypothesize that, in an upwelling sub-ridge setting, sulfide will tend to "pond" just above the sulfide solidus ( $160 \mathrm{~km}$ depth). We expect the sulfide here to be wetting, and to form an interconnected melt network that will enhance the gravitational segregation and downward ponding of sulfide melt. Much of this sulfide will "turn the corner" as the mantle "carrier" exits the upwelling sub-ridge flow regime. Ultimately, this sulfide will "solidify" near the bottom of oceanic plates, and tend to be returned to the deep mantle during subduction. As this sulfide is located on the underside of the plate, it will be relatively immune to the complex processes affecting the surface of the plate and mantle wedge. If the subducted plate were to reach the bottom of the mantle, and enter the core-mantle boundary layer, temperatures there are high enough to re-melt the sulfide, again freeing it to segregate and percolate downwards, eventually perhaps actually becoming entrained into the core. If this process has occurred over geologic time, it would represent a continuing "one-way" flux of $\mathrm{Pb}$ into the core, leaving behind a silicate mantle impoverished in $\mathrm{Pb}$ (relative to $\mathrm{U}$ ), and providing a solution for both the First $\mathrm{Pb}$ 
Paradox (as proposed by Vidal and Dosso 1978) and the Third Pb Paradox. This longterm sequestering of $\mathrm{Pb}$ into the core will not violate the $\mathrm{Hf}-\mathrm{W}$ constraints on core formation age, as W is not appreciably chalcophile (Gaetani and Grove 1997). Full elucidation of this process must await experiments on both $\mathrm{Pb}$ partitioning between sulfide and silicate, and the wetting properties of sulfide melt, at lower mantle P-T conditions.

The extent to which sulfide melt can pond on its solidus during sub-ridge upwelling will depend on the details of inter-granular migration velocities; this will require formal dynamic modeling. Whatever sulfide melt is present as the upwelling mantle reaches the silicate solidus will then become trapped as it converts into non-wetting globules in the presence of silicate melt. This sulfide may get entrained and erupted along with the silicate melt, or some of it may remain trapped in the inter-granular network, and ultimately become part of the oceanic lithosphere - again possibly being returned to the deep mantle during plate subduction.

\section{ACKNOWLEDGEMENTS}

We are grateful to J. Brenan and an anonymous referee for thoughtful and constructive comments. As always, we are grateful to the Geochemistry Seminar at WHOI for their stimulation and enthusiasm, and their incitement to excess. Or to re-cast Einstein, "Every paper should be as daring as possible, but not more". Our intemperance should not be blamed on the support we gratefully acknowledge from NSF: EAR0125917 to SRH and OCE-0118198 to GAG. 


\section{REFERENCES}

Allègre CJ (1982) Chemical Geodynamics. Tectonophysics 81:109-132

Allègre CJ, Brévart O, Dupré B, Minster J-F (1980) Isotopic and chemical effects produced in a continuously differentiating convecting Earth mantle. Phil. Trans. R. Soc. Lond. A 297:447-477

Allègre CJ, Dupré B, Brévart O (1982) Chemical aspects of the formation of the core. Phil. Trans. R. Soc. Lond. A 306:49-59

Asimow PD, Dixon JE, Langmuir CH (2004) A hydrous melting and fractionation model for mid-ocean ridge basalts: Application to the Mid-Atlantic Ridge near the Azores. Geochemistry, Geophysics, Geosystems 5:Q01E16, doi:10.1029/2003GC000568

Asimow PD, Hirschmann MM, Ghiorso MS, O'Hara JJ, Stolper EM (1995) The effect of pressure-induced solid-solid phase transitions on decompression melting of the mantle. Geochimica Cosmochimica Acta 59:4489-4506

Ballhaus C, Ellis DJ (1996) Mobility of core melts during Earth's accretion. Earth and Planetary Science Letters 143:137-145

Barnes SJ, Mavovicky E, Makovicky M, Rose-Hansen J, Karup-Moller S (1997) Partition coefficients for $\mathrm{Ni}, \mathrm{Cu}, \mathrm{Pd}, \mathrm{Pt}, \mathrm{Rh}$, and Ir between monosulfide solid solution and sulfide liquid and the formation of compositionally zoned $\mathrm{Ni}-\mathrm{Cu}$ sulfide bodies by fractional crystallization of sulfide liquid. Can. J. Earth Science 34:366-374

Barnes SJ, Peregoedova A, Baker D, Maier WD (2004) Incongruent Melting of Monosulfide Solid Solution and its Implications for Fractionation of the Platinumgroup elements During Partial Melting of the Mantle (Abstract). In: EOS, vol 85. AGU, p 508

Bézos A, Lorand J-P, Humler E, Gros M (2005) Platinum-group element systematics in Mid-Oceanic Ridge basaltic glasses from the Pacific, Atlantic, and Indian Oceans. Geochimica et Cosmochimica Acta 69:2613-2627

Bockrath C, Ballhaus C, Holzheid A (2004) Fractionation of the Platinum-Group elements during mantle melting. Science 305:1951-1953

Brenan JM, McDonough WF (2005) Fractionation of Highly Siderophile Elements (HSEs) by Sulfide-Silicate Partitioning: A New Spin. EOS 86:52 (poster version and personal communication).

Brenan JR, Cherniak DJ, Rose LA (2000) Diffusion of osmium in pyrrhotite and pyrite: implications for closure of the Re-Os isotopic system. Earth and Planetary Science Letters 180:399-413 
Carignan J, Ludden J, Francis D (1996) On recent enrichment of subcontinental lithosphere: a detailed U-Pb study of spinel lherzolite xenoliths, Yukon, Canada. Geochimica et Cosmochimica Acta 60:4241-4252

Condit RH, Hobbins RR, Birchenall DE (1974) Self-diffusion of iron and sulfur in ferrous sulfide, in Oxidation and Metals. In, vol 8. pp 408-455

de Bremond d'Ars J, Arndt NT, Hallot E (2001) Analog experimental insights into the formation of magmatic sulfide deposits. Earth and Planetary Science Letters 186:371381

Dobson DP (2000) Fe and Co tracer diffusion in liquid Fe-FeS at 2 and 5 GPa. Physics of the Earth and Planetary Interiors 120:137-144

Dobson DP, Crichton WA, Vocadlo L, Jones AP, Wang Y, Uchida T, Rivers M, Sutton ST, Brodholt JP (2000) In situ measurement of viscosity of liquids in the Fe-FeS system at high pressures and temperatures. American Mineralogist 85:1838-1842

Ebel DS, Naldrett AJ (1996) Fractional Crystallization of Sulfide Ore Liquids at High Temperature. Economic Geology 91:607-621

Eggler DH, Lorand JP (1993) Mantle sulfide geobarometry. Geochimica Cosmochimica Acta 57:2213-2222

Eisele J, Sharma M, Galer SJG, Blichert-Toft J, Devey CW, Hofmann AW (2002) The role of sediment recycling in EM-1 inferred from $\mathrm{Os}, \mathrm{Pb}, \mathrm{Hf}, \mathrm{Nd}, \mathrm{Sr}$ isotope and trace element systematics of the Pitcairn hotspot. Earth and Planetary Science Letters 196:197-212

Fleet ME, Crocket JH, Stone WE (1996) Partitioning of platinum-group elements (Os, Ir, $\mathrm{Ru}, \mathrm{Pt}, \mathrm{Pd}$ ) and fold between sulfide liquid and basalt melt. Geochimica et Cosmochimica Acta 60:2397-2412

Fleet ME, Tronnes RG, Stone WE (1991) Partitioning of Platinum Group Elements in the Fe-O-S System to $11 \mathrm{GPa}$ and Their Fractionation in the Mantle and Meteorites. Journal of Geophysical Research 96:21,949-21,958

Gaetani GA, Grove TL (1997) Partitioning of moderately siderophile elements among olivine, silicate melt, and sulfide melt: Constraints on core formation in the Earth and Mars. Geochimica Cosmochimica Acta 61: 1829-1846

Gaetani GA, Grove TL (1999) Wetting of mantle olivine by sulfide melt: implications for $\mathrm{Re} / \mathrm{Os}$ ratios in mantle peridotite and late stage core formation. Earth and Planetary Science Letters 169: 147-163

Gao S, Luo T-C, Zhang B-R, Zhang H-F, Han Y-W, Zhao Z-D, Hu Y-K (1998) Chemical composition of the continental crust as revealed by studies in East China. Geochimica et Cosmochimica Acta 62:1959-1975 
Garuti G, Gorgoni C, Sighinolfi GP (1984) Sulfide mineralogy and chalcophile and siderophile element abundances in the Ivrea-Verbano mantle peridotites (Western Italian Alps). Earth and Planetary Science Letters 70:69-87

Godard M, Kelemen P, Hart S, Jackson M, Hanghoj K (2005) High Pb/Ce reservoir in depleted altered mantle peridotites. Eos Trans. 86:F1937

Hart SR, Zindler A (1986) In search of a bulk-earth composition. Chemical Geology $57: 247-267$

Hart SR, Ravizza G (1996) Osmium partitioning between phases in lherzolite and basalt. In: Basu A, Hart SR (eds) Earth Processes: Reading the Isotopic Code, vol., pp 123134

Hart, S R, Dunn T (1993) Experimental cpx/melt partitioning for 24 trace elements. Contr. Miner. Petrology 113:1-8

Hauri EH, Hart SR (1997) Rhenium abundances and systematics in oceanic basalts. Chemical Geology 139:185-205

Hauri EH, Wagner TP, Grove TL (1994) Experimental and natural partitioning of Th, U, $\mathrm{Pb}$ and other trace element between garnet, clinopyroxene and basaltic melts. Chemical Geology 117:149-166

Hirschmann MM (2000) Mantle solidus: Experimental constraints and the effect of peridotite composition. Geochemistry, Geophysics, Geosystems 1:2000GC000070

Hofmann AW (1988) Chemical differentiation of the Earth: the relationship between mantle, continental crust, and oceanic crust. Earth and Planetary Science Letters 90:297-314

Hofmann A (2003) Sampling Mantle Heterogeneity through Oceanic Basalts: Isotopes and Trace Elements. In: Holland HD, Turekian KK (eds) Treatise on Geochemistry, vol 2.03. pp 61-101

Hofmann AW, Jochum KP, Seufert HM, White WM (1986) $\mathrm{Nb}$ and $\mathrm{Pb}$ in oceanic basalts: new constraints on mantle evolution. Earth and Planetary Science Letters $79: 33-45$

Ionov DA, Chazot G, Chauvel C, Merlet C, Bodinier J-L (2006) Trace element distribution in peridotite xenoliths from Tok, SE Siberian craton: A record of pervasive, multi-stage metasomatism in shallow refractory mantle. Geochimica Cosmochimica Acta 70:1231-1260

Ionov AD, Hoefs J, Wedepohl KH, Weichert U (1992) Content and isotopic composition of sulphur in ultramafic zenoliths from central Asia. Earth and Planetary Science Letters 111:269-286 
Jacobsen SB (2003) How Old Is Planet Earth? Science 300:1513-1514

Jagoutz E, Palme H, Badenhausen H, Blum K, Cendales M, Dreibus G, Spettel G, Lorenz V, Wanke H (1979) The abundances of major, minor and trace elements in the Earth's mantle as derived from primitive ultramafic nodules. In: Proc. 10th Lunar Planet. Sci. Conf., vol., pp 2031-2050

Jones JH, Hart SR, Benjamin TM (1993) Experimental Partitioning Studies near the FeFeS eutectic, with an emphasis on elements important to iron meteorite chronologies $\mathrm{Pb}, \mathrm{Ag}, \mathrm{Pd}$ and $\mathrm{Tl}$. Geochimica et Cosmochimica Acta 57:453-460

Jugo PJ, Luth RW, Richards JP (2005) Experimental data on the speciation of sulfur as a function of oxygen fugacity in basaltic melts. Geochimica et Cosmochimica Acta 69:497-503

Kelemen PB, Yogodzinski GM, Scholl DW (2004) Along-strike variation in lavas of the Aleutian island arc: Genesis of high Mg\# andesite and implications for continental crust. In: Eiler J (ed) Inside the Subduction Factory, vol 138. American Geophysical Union, Washington, DC

Keshav S, Corgne A, Gudfinnsson GH, Bizmis M, McDonough WF, Fei Y (2005) Kimberlite petrogenesis: Insights from clinopyroxene-melt partitioning experiments at $6 \mathrm{GPa}$ in the $\mathrm{CaO}-\mathrm{MgO}-\mathrm{Al}_{2}-\mathrm{SiO}_{2}-\mathrm{CO}_{2}$ system. Earth and Planetary Science Letters $168: 287-299$

Kleine T, Mezoer K, Münker C, Palme H, Bichoff A (2004) ${ }^{182} \mathrm{Hf}^{182} \mathrm{~W}$ isotope systematics of chondrites, eucrites, and martian meteorites: Chronology of core formation and early mantle differentiation in Vesta and Mars. Geochimica et Cosmochimica Acta (68):2935-2946

Kleine T, Münker C, Mezger K, Palme H (2002) Rapid accretion and early core formation on asteroids and the terrestrial planets from Hf-W chronometry. Nature 418:952-955

Klemme S, Blundy JD, Wood BJ (2002) Experimental constraints on major and trace element partitioning during partial melting of eclogite. Geochimica et Cosmochimica Acta 66:3109-3123

Li C, Barnes S-J, Makovicky E, Rose-Hansen J, Makovicky M (1996) Partitioning of nickel, copper, iridium, rhenium, platinum, and palladium between monosulfide solid solution and sulfide liquid: Effects of composition and temperature. Geochimica et Cosmochimica Acta 60:1231-1238

Lorand J-P (1991) Sulphide Petrology and Sulphur Geochemistry of Orogenic Lherzolites: A Comparative Study of the Pyrenean Bodies (France) and Lanzo Massif (Italy). Journal of Petrology Special Lherzolites Issue:77-95 
Lorand J-P, Alard O, Luguet A, Keays RR (2003) Sulfur and selenium systematics of the subcontinental lithospheric mantle: Inferences from the Massif Central xenolith suite (France). Geochimica et Cosmochimica Acta 67:4137-4151

Lundstrom CC, Shaw HF, Ryerson FJ, Williams Q, Gill J (1998) Crystal chemical control of clinopyroxene-melt partitioning in the Di-Ab-An system: Implications for elemental fractionations in the depleted mantle. Geochimica et Cosmochimica Acta 62:2849-2862

Mavrogenes JA, O'Neill HSC (1999) The relative effects of pressure, temperature and oxygen fugacity on the solubility of sulfide in mafic magmas. Geochimica et Cosmochimica Acta 63:1173-1180

McCulloch MT, Bennett VC (1994) Progressive growth of the Earth's continental crust and depleted mantle. Geochimica et Cosmochimica Acta 58:4717-4738

McDonough WF, Sun S-s (1995) The composition of the Earth. Chemical Geology $120: 223-253$

Meijer A, Kwon T-T, Tilton GR (1990) U-Th-Pb partitioning Behavior During Partial Melting in the Upper Mantle: Implications for the Origin of High Mu Components and the "Pb Paradox." Journal of Geophysical Research 95:433-448

Minarik WG, Ryerson FJ, Watson EB (1996) Textural Entrapment of Core-Forming Melts. Science 272:530-533

Moretti R, Ottonello G (2005) Solubility and speciation of sulfur in silicate melts: The Conjugated Toop-Samis-Flood-Grjotheim (CTSFG) model. Geochimica et Cosmochimica Acta 69:801-823

Mungall JE, Su S (2005) Interfacial tension between magmatic sulfide and silicate liquids: Constraints on kinetics of sulfide liquation and sulfide migration through silicate rocks. Earth Planetary Science Letters 234:135-149

O'Neill H, Mavrogenes J (2002) The sulfide capacity and the sulfur content at sulfide saturation of silicate melts at $1400^{\circ} \mathrm{C}$ and 1 bar. Journal of Petrology 43:1049-1087

O'Nions RK, Evenson NM, Hamilton PJ (1979) Geochemical modeling of mantle differentiation and crustal growth. J. Geophys. Rec. 84:6091-6101

Oversby VM, Ringwood AE (1971) Time of formation of earth's core. Nature 237:463465

Peach CL, Mathez EA (1993) Sulfide melt-silicate melt distribution coefficients for nickel and iron and implications for the distribution of other chalcophile elements. Geochimica Cosmochimica Acta 57:3013-3021 
Peach CL, Mathez EA, Keays RR, Reeves SJ (1994) Experimentally determined sulfide melt-silicate melt partition coefficients for iridium and palladium. Chemical Geology $117: 361-377$

Peucker-Ehrenbrink B, Hofmann AW, Hart SR (1994) Hydrothermal lead tranfer from mantle to continental crust: the role of metalliferous sediments. Earth and Planetary Science Letters 125:129-142

Pickering-Witter J, Johnston AD (2000) The effects of variable bulk composition on the melting systematics of fertile peridotitic assemblages. Contrib. Mineral. Petrology 140:190-211

Rose LA, Brenan JM (2001) Wetting properties of Fe-Ni-Co-Cu-O-S melts against olivine: implications for sulfide mobility. Economic Geology 96:145-157

Rudnick RL, Fountain DM (1995) Nature and composition of the continental crust: a lower crustal perspective. Review of Geophysics 33:267-309

Ryzhenko B, Kennedy GC (1973) The Effect of Pressure on the Eutectic in the System Fe-FeS. American Journal of Science 273:803-810

Salters VJM, Longhi JE, Bizimis M (2002) Near mantle solidus trace element partitioning at pressures up to $3.4 \mathrm{GPa}$. Geochemistry, Geophysics, Geosystems 3(7):10.1029/2001GC000148

Sattari P, Brenan JM, Horn I, McDonough WF (2002) Experimental constraints on the Sulfide- and Chromite-Silicate Melt Partitioning Behavior of Rhenium and PlatinumGroup Elements. Economic Geology 97:385-398

Schmidt KH, Bottazzi P, Vannucci R, Mengel K (1999) Trace element partitioning between phlogopite, clinopyroxene and leucite lamproite melt. Earth and Planetary Science Letters 168:287-299

Shimazaki K, MacLean WH (1976) An experimental study on the partition of zinc and lead between the silicate and sulfide liquids. Miner. Deposita 11:125-132.

Sims KWW, DePaolo DJ (1997) Inferences about mantle magma sources from incompatible element concentration ratios in oceanic basalts. Geochimica Cosmochimica Acta 61:765-784

Smith CS (1964) Some elementary principles of polycrystalline microstructure. Metallurgical Reviews 9(33):1-48

Stacey JS, Kramers JD (1975) Approximation of terrestrial lead isotope evolution by a two-stage model. Earth Planetary Science Letters 26:207-221 
Su Y, Langmuir CH (2003) Global MORB chemistry compilation at the segment scale. In: Department of Earth and Environmental Sciences, vol. Columbia University, New York

Sun S-S (1980) Lead isotopic study of young volcanic rocks from mid-ocean ridges, ocean islands and island arcs. Phil. Trans. R. Soc. Lond. A 297:409-445

Szabo C, Bodnar RJ (1995) Chemistry and origin of mantle sulfides in spinel peridotite xenoliths from alkaline basaltic lavas, Nógrád-Gömör Volcanic Field, northern Hungary and southern Slovakia. Geochimica et Cosmochimica Acta 59:3917-3927

Tatsumoto M, Basu AR, Wankang H, Junwen W, Guanghong X (1992) Sr, Nd, and Pb isotopes of ultramafic xenoliths in volcanic rocks of Eastern China: enriched components EMI and EMII in subcontinental lithosphere. Earth and Planetary Science Letters 113:107-128

Terasaki H, Frost DJ, Rudie DC, Langenhorst F (2005) The effect of oxygen and sulphur on the dihedral angle between Fe-O-S melt and silicate minerals at high pressure: implications for Martian core formation. Earth and Planetary Science Letters 232:379-392

Urakawa S, Kato M, Kumazawa M (1987) Experimental study of the phase relations in the system Fe-Ni-O-S up to 15 Gpa. pp 95-111 In High Pressure Research in Mineral Physics, Manghnani MH, Syono Y eds, American Geophysical Union, Washington, $\mathrm{DC}$

Vidal P, Dosso L (1978) Core formation: Catastrophic or continuous? Sr and $\mathrm{Pb}$ isotope geochemistry constraints. Geophysical Research Letters 5:169-172

Vollmer R (1977) Terrestrial lead evolution and formation time of the Earth's core. Nature 270:144-147

von Bargen N, Waff HS (1986) Permeabilities, interfacial areas and curvatures in partially molten systems: results of numerical computations of equilibrium microstructures. J Geophys Res 91:9261-9276

Walter MJ (1998) Melting of Garnet Peridotite and the Origin of Komatiite and Depleted Lithosphere. Journal of Petrology 39(1):29-60

Wasylenki LE, Baker MB, Kent AJR, Stolper EM (2003) Near-solidus Melting of the Shallow Upper Mantle: Partial Melting Experiments on Depleted Peridotite. Journal of Petrology 44(7):1163-1191

Witt-Eickscen G, O'Neill H (2005) The effect of temperature on the equilibrium distribution of trace elements between clinopyroxene, orthopyroxene, olivine and spinel in upper mantle peridotite. Chemical Geology 221:65-101 
Woodhead JD (1996) Extreme HIMU in an oceanic setting: the geochemistry of Mangaia Island (Polynesia), and temporal evolution of the Cook-Austral hotspot. Journal of Volcánology and Geothermal Research 72:1-19

Workman RK, Hart SR (2005) Major and Trace Element Composition of the Depleted MORB Mantle (DMM). Earth and Planetary Science Letters 231:53-72

Workman RK, Hart SR, Jackson M, Regelous M, Farley KA, Blusztajn J, Kurz M, Staudigel H (2004) Recycled metasomatized lithosphere as the origin of the enriched mantle II (EM2) end-member: evidence from the Samoan volcanic chain. Geochemistry, Geophysics, Geosystems 5:doi: 10.1029/2003GC000623

Yang L, Kado S, Derge G (1959) Diffusion in Molten Sulfides. In: Kingery WD (ed) Kinetics of High Temperature Processes, vol. Wiley, New York, pp 79-80

Yoshino T, Walter MJ, Katsura T (2004) Connectivity of molten Fe alloy in peridotite based on in situ electrical conductivity measurements: implications for core formation in terrestrial planets. Earth and Planetary Science Letters 222:625-643

Zartman RE, Haines SM (1988) The plumbotectonic model for Pb isotopic systematics among major terrestrial reservoirs - a case for bi-directional transport. Geochimica Cosmochimica Acta 52:1327-1339

Zindler A, Hart SR (1986) Chemical Geodynamics. Annual Reviews Earth and Planetary Sciences 14:493-571 


\section{Figure CAPTions}

Figure 1. ${ }^{207} \mathrm{~Pb} /{ }^{204} \mathrm{~Pb}-{ }^{206} \mathrm{~Pb} /{ }^{204} \mathrm{~Pb}$ growth curve for the earth, with a 4.534 g.y. Geochron, secondary isochrons of $2 \mathrm{~g} . \mathrm{y}$. and $3 \mathrm{~g}$.y., and a representative sample of $\mathrm{Pb}$ isotopic compositions for MORB and OIB. Primordial $\mathrm{Pb}$ was taken as Canyon Diablo, major $\mathrm{U} / \mathrm{Pb}$ fractionation was assumed to be finished by the end of core formation, $\sim 4.534 \mathrm{~g}$.y. $\mathrm{A}^{238} \mathrm{U} /{ }^{204} \mathrm{~Pb}=8.25$ growth curve was chosen so as to terminate on the Geochron at the same place as the intersection defined by the MORB and OIB array (which array lies approximately along a 2 g.y. secondary isochron).

Figure 2. Hofmann plot of $\mathrm{Nd} / \mathrm{Pb}$ versus $\mathrm{Nd}$ concentration for a selection of "endmember" basalts from Samoa, Pitcairn, Mangaia and global average N-MORB (data from Workman et al. 2004; Eisele et al. 2002; Woodhead 1996; Hauri and Hart 1997; Hofmann 1988; Su and Langmuir 2003; and Hauri, Hart and Farley unpublished). The dotted line represents the $\mathrm{Nd} / \mathrm{Pb}$ ratio of Bulk Silicate Earth (BSE; McDonough and Sun 1995). All of this data is of "modern" quality, on basalts selected for freshness; the significant scatter is probably real, and may reflect both source variations, and the variable impact of sulfide control during melting and melt transport. The endmembers have statistically distinct $\mathrm{Nd} / \mathrm{Pb}$ ratios $(2 \sigma$ standard errors): EM1 $-10.2 \pm 0.3$; HIMU $15.9 \pm 1.0 ; \mathrm{EM} 2-11.9 \pm 0.7 ; \mathrm{NMORB}=22.9$.

Figure 3. Spidergram showing basalts from oceanic mantle end-members, normalized to bulk silicate earth of McDonough and Sun (1995); (based on our unpublished work, we have used $0.010 \mathrm{ppm}$ for Cs normalizing). HIMU - average of 21 samples from Mangaia and Tubuai Islands; average 206/204 Pb = 21.48 (Woodhead 1996; Hauri and Hart 1997). EM1 - average of 18 samples of Tedside Series, Pitcairn Island; average 206/204 Pb = 17.75 (Eisele et al. 2002 and Hauri, Hart and Farley, unpublished). EM2 - average of 6 samples from Malumalu seamount, Samoa; average 87/86 Sr $=0.7078$ (Workman et al. 2004). N-MORB - combined global average; 143/144 Nd =0.51313 (Hofmann 1988; $\mathrm{Su}$ and Langmuir 2003). Mg-numbers for these averages are 0.60, 0.60, 0.63 and 0.62 respectively.

Figure 4. Phase relations of $\mathrm{Fe}+\mathrm{Ni}+\mathrm{Cu}$ monosulfide, adapted from Bockrath et al. (2004). Filled squares are subsolidus sulfides, half-filled squares are monosulfide-melt pairs and open circles are superliquidus runs (quenched monosulfides). Thin solid lines marked sulfide solidus and sulfide liquidus are as interpreted by Bockrath et al. (2004) from their experiments. We have added the parameterized anhydrous solidus for natural peridotites from Hirschmann (2000), heavy solid line, and the univariant melting temperature for stoichiometric FeS (troilite) from Ryzhenko and Kennedy (1973), dashed line.

Figure 5. Abbreviated spidergram for a peridotite whole rock composition reconstructed from analyses of highly-purified silicate minerals from peridotite xenolith DH41087 (Meijer et al. 1990). For comparison, we also plot the average of 6 whole rock peridotites from Tatsumoto et al. (1992), that show only a minimal negative $\mathrm{Pb}$ anomaly. Both the Meijer at al (1990) and Tatsumoto et al (1992) data are by high quality isotope dilution 
techniques. Also shown, for guidance, is the spidergram for the upper MORB mantle (dashed line), from Workman and Hart (2005).

Figure 6. Sulfur content of basalt in equilibrium with sulfide during various mantle upwelling P-T trajectories. Sulfur saturation parameterization is from Mavrogenes and O’Neill (1999), for basaltic melt saturated with FeS. The study of O'Neill and Mavrogenes (2002) provides a parameterization with more detailed consideration of the effects of melt composition, but does not alter the qualitative aspects shown in this figure. Curves are shown for a potential temperature of $1500^{\circ} \mathrm{C}$; with the peridotite solidus of Hirschmann (2000), this leads to melt initiation at $\sim 110 \mathrm{~km}$, as would be appropriate for an OIB. The adiabat (single-phase solid or melt) is taken as $0.4^{\circ} \mathrm{C} / \mathrm{km}$; the P-T trajectory of upwelling residual mantle as melt is continuously generated and extracted is approximated from Asimow et al. $(1995,2004)$. At shallow depths, this trajectory is schematic only, as the effects of conductive cooling and differentiation are ignored.

Figure 7. (a) Plot illustrating the change in the oxygen content of anion-rich Fe-Ni-Cu sulfide melt as a function of oxygen fugacity, relative to the fayalite-magnetite-quartz buffer at $\log _{\mathrm{S} 2} \sim 2.0$. The high-pressure experiments of Peach and Mathez $1993(0.8$ $\mathrm{GPa}, 1450^{\circ} \mathrm{C}$ ) are shown as filled symbols; experiments carried out at 1 bar and $1300^{\circ} \mathrm{C}$ (Rose and Brenan 2001) or $1350^{\circ} \mathrm{C}$ (Gaetani and Grove 1999) are shown as shaded symbols. Error bars are $1 \sigma$ based on replicate analyses. Note that no uncertainties were reported for the experiments of Peach and Mathez (1993). (b) Plot showing the relationship between the oxygen content of anion-rich Fe-Ni- $( \pm \mathrm{Cu})$ sulfide melt and the olivine-sulfide melt dihedral angle. The high-pressure experiment of Minarik et al. (1996) $\left(3.9 \mathrm{GPa}, 1500^{\circ} \mathrm{C}\right)$ is shown as a filled symbol; experiments carried out at 1 bar and $1300^{\circ} \mathrm{C}$ (Rose and Brenan 2001) or $1350^{\circ} \mathrm{C}$ (Gaetani and Grove 1999) are shown as shaded symbols. All uncertainties are $1 \sigma$.

Figure 8. Peridotite melting models showing $\mathrm{Nd}$ and $\mathrm{Pb}$ concentrations in silicate melt (basalt) during melting in the presence of a sulfide phase. The starting peridotite is assumed to have "bulk earth" contents of $\mathrm{Nd}$ and $\mathrm{Pb}$ (1.25 ppm and $0.15 \mathrm{ppm}$; large filled circle labeled BSE). Modal mineralogy, melting reactions, and mineral partition coefficients are given in Table 1. For the simple aggregated fractional modal melting of spinel peridotite and garnet peridotite (upper panel), a constant sulfur saturation in the melt of $1200 \mathrm{ppm}$ is used, and the sulfide/silicate melt $\mathrm{K}_{\mathrm{d}}$ for $\mathrm{Pb}$ is adjusted to give an initial melt with a bulk earth $\mathrm{Nd} / \mathrm{Pb}$ ratio $\left(\mathrm{K}_{\mathrm{d}}\right.$ of 49.9 for spinel peridotite and 44.3 for garnet peridotite). A more realistic melting model is also shown, where a constant melt production of $0.22 \% / \mathrm{km}$ is assumed, and melting starts at $110 \mathrm{~km}$ in the garnet facies, followed by further melting in the spinel facies from 92 to $65 \mathrm{~km}$. An aggregated fractional non-modal melting model is used (see table 1 for the parameters utilized), with 0 to $4 \%$ melt derived from the garnet facies, and $4 \%$ to $10 \%$ from the spinel facies. $\mathrm{S}$ saturation in the silicate melt is continuously varied along the "residual mantle" saturation curve of Fig. 6, thus varying from $1000 \mathrm{ppm}$ at melt initiation, and finishing at $1400 \mathrm{ppm}$ when melting ends at $\mathrm{F}=10 \%$. This leads to a gradually decreasing modal sulfide content, from $0.066 \%$ at melt initiation to $0.034 \%$ at $\mathrm{F}=10 \%$. The sulfide $/$ silicate 
melt $\mathrm{K}_{\mathrm{d}}$ for $\mathrm{Pb}$ is chosen to provide an initial melt with "bulk earth" $\mathrm{Nd} / \mathrm{Pb}$; in this case $\mathrm{K}_{\mathrm{d}}=44.2$.

In the lower panel, the dependence of the $\mathrm{Nd} / \mathrm{Pb}$ trajectory on sulfide/silicate melt $\mathrm{K}_{\mathrm{d}}$ is shown, for values of 35, 44 (as in the upper panel) and 55. The model is for nonmodal garnet to spinel melting, using the same parameters as in the upper panel. 


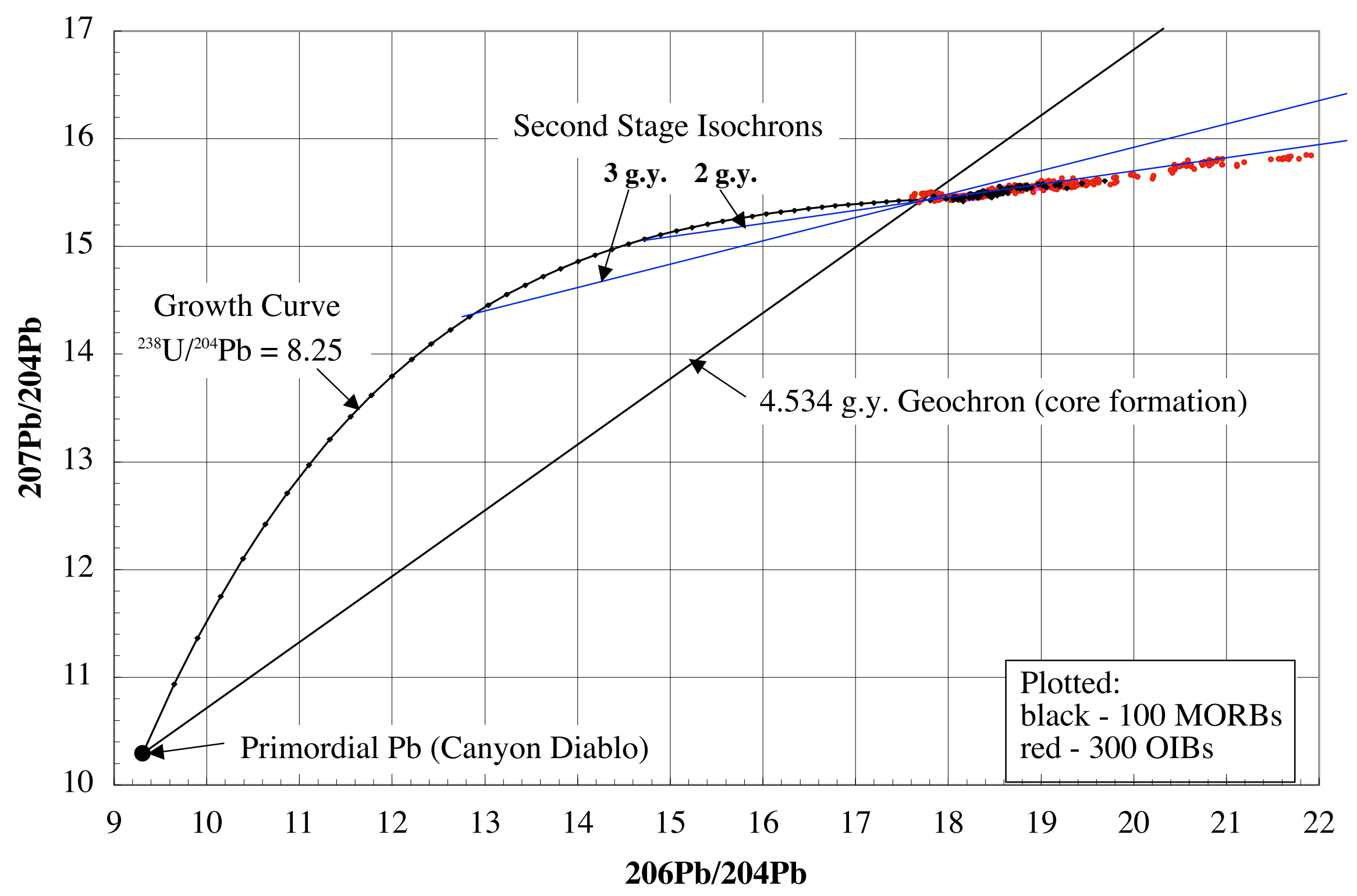

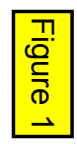




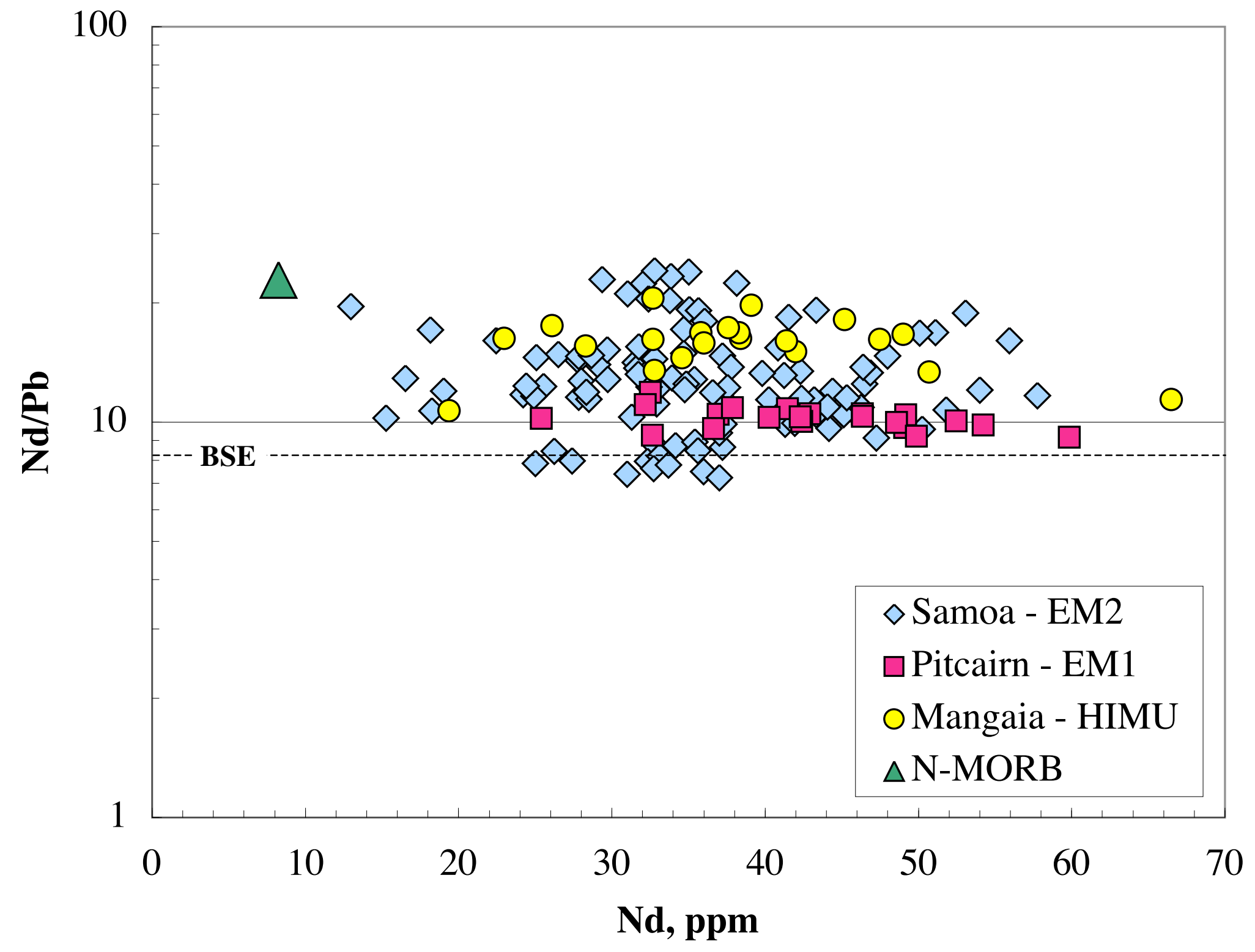




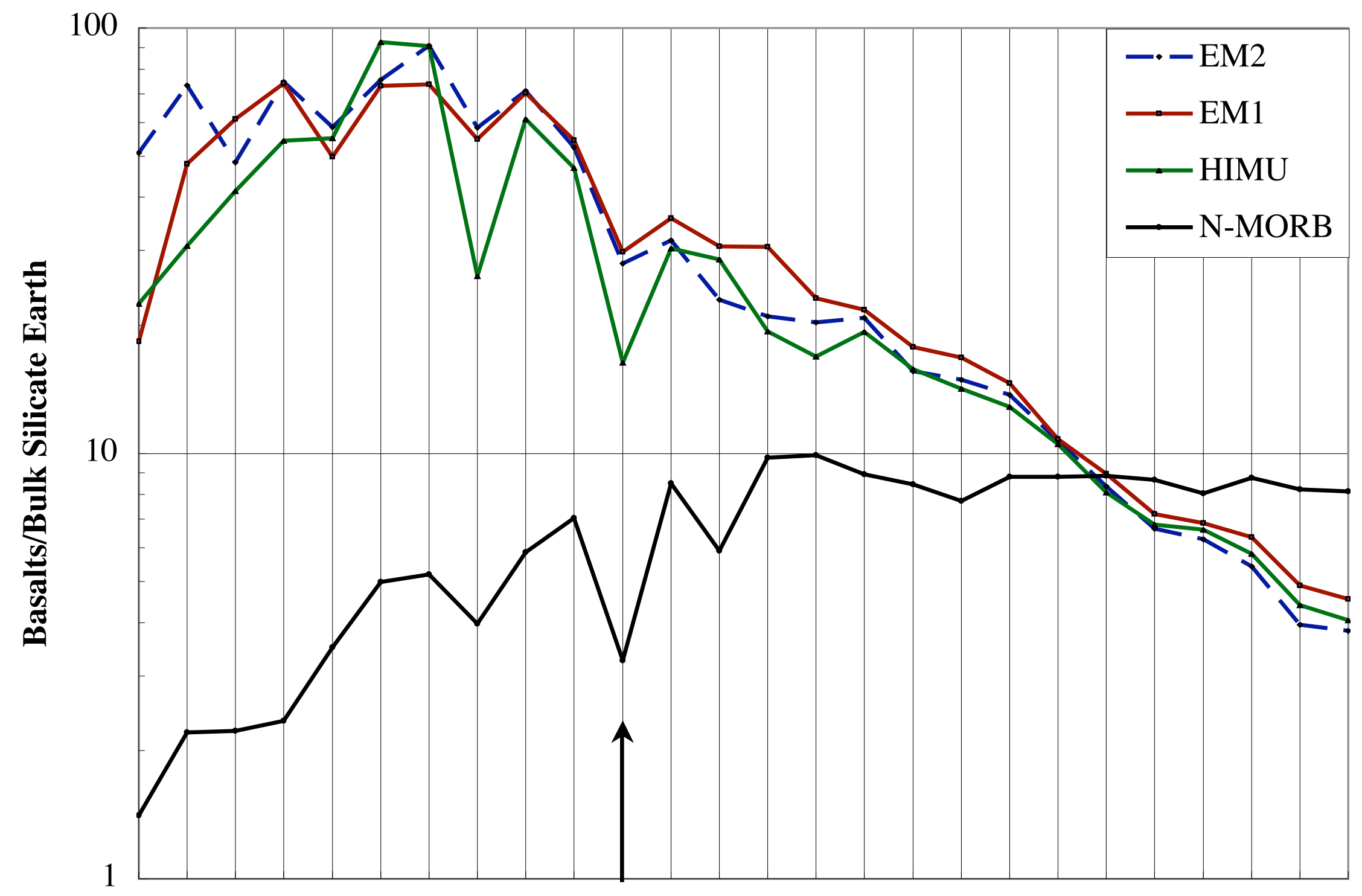

Cs $\mathrm{Rb} \mathrm{Ba}$ Th $\mathrm{U}$ Nb Ta K La Ce Pb Nd Sr Zr Hf Sm Eu Ti Gd Tb Dy Ho Y Er Yb Lu 


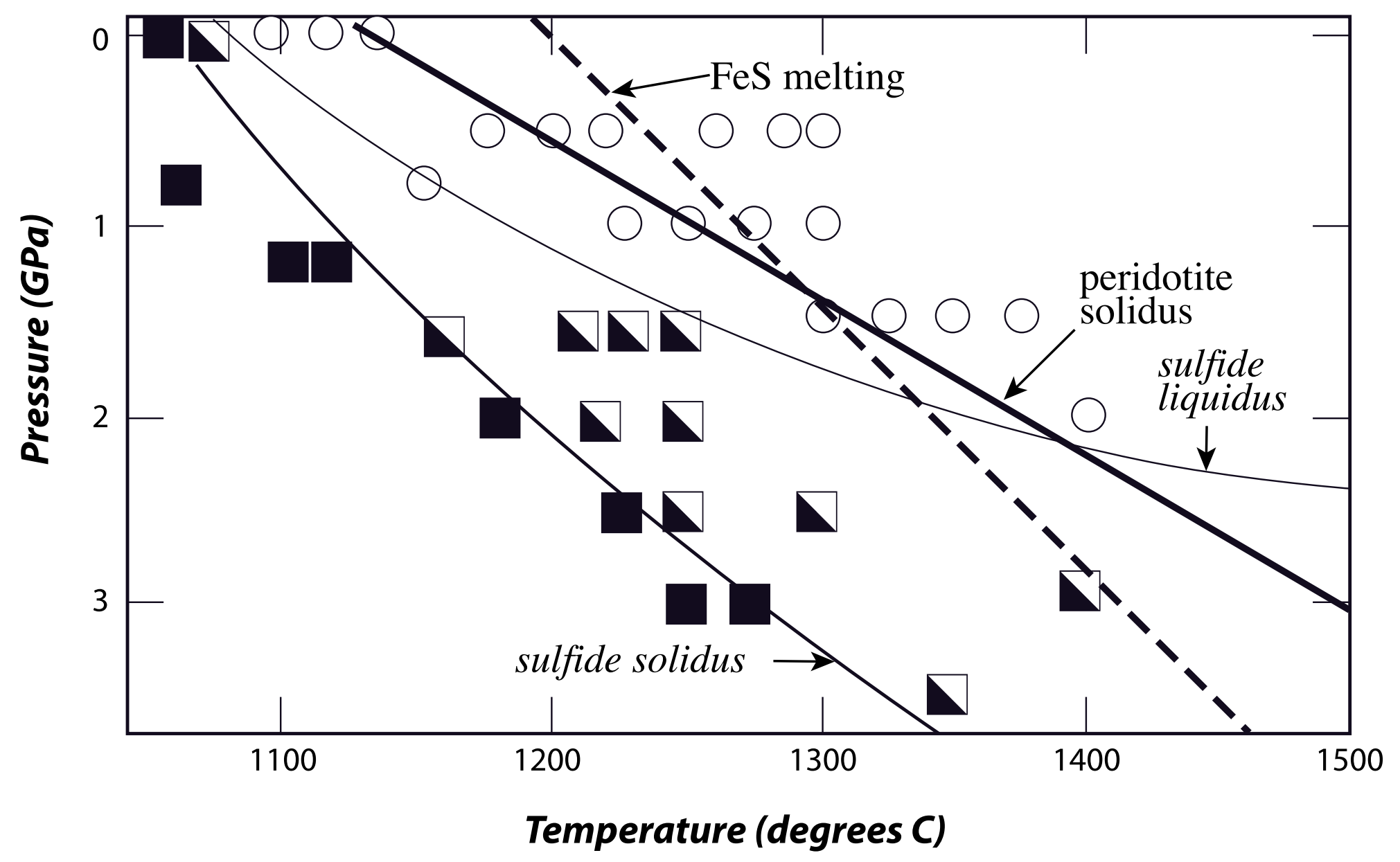




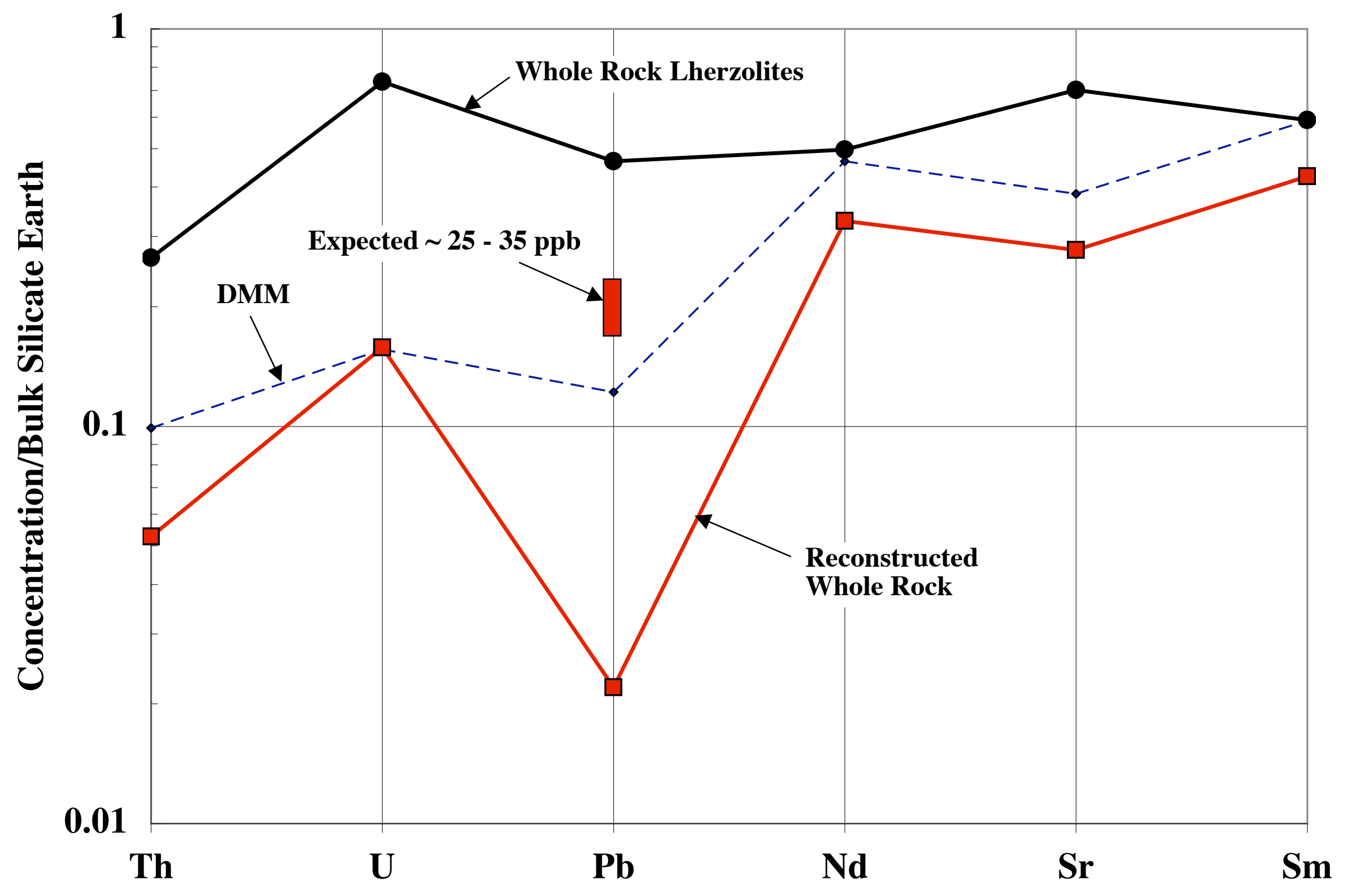


Sulfur Saturation, ppm

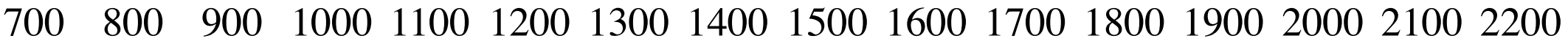

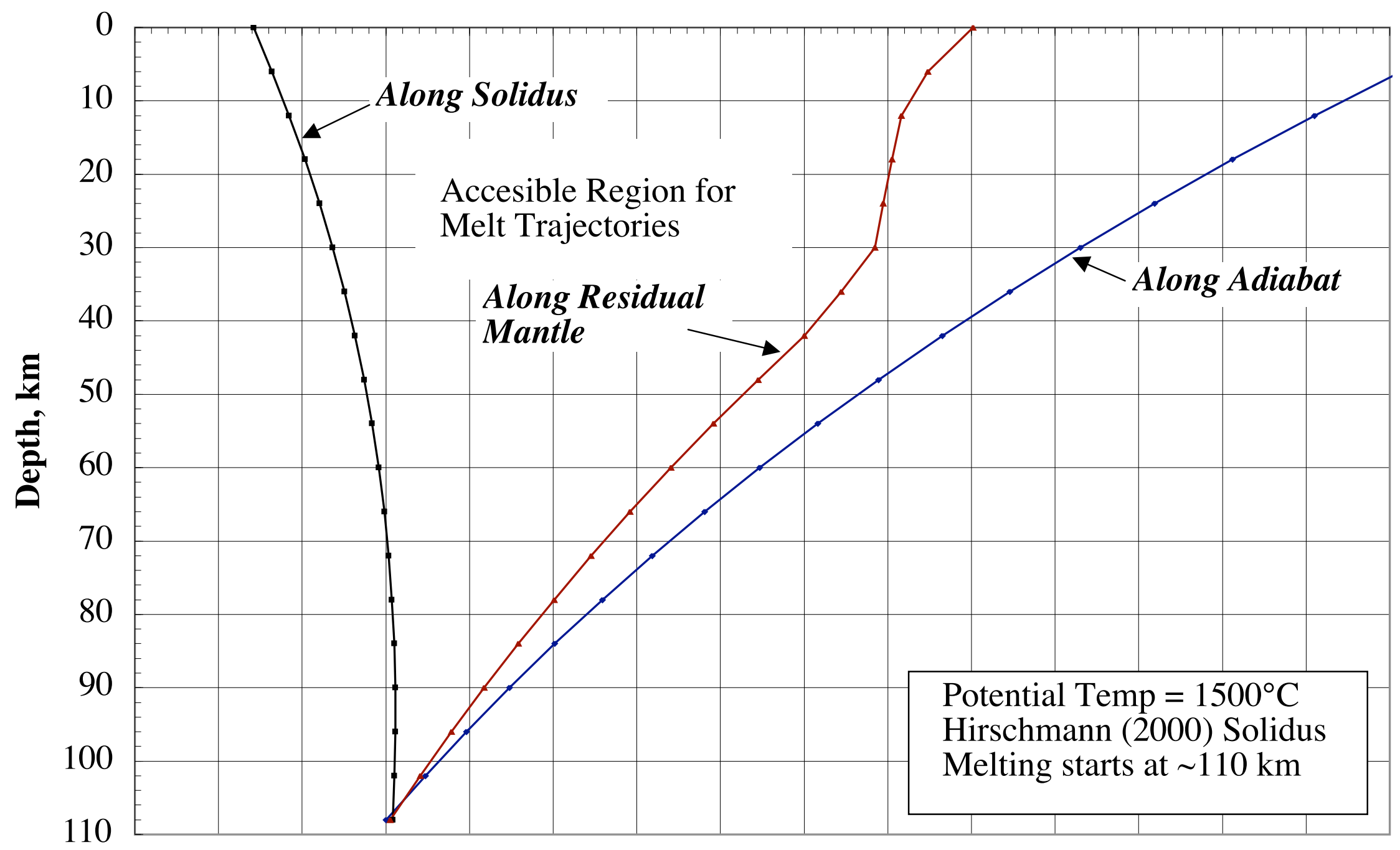




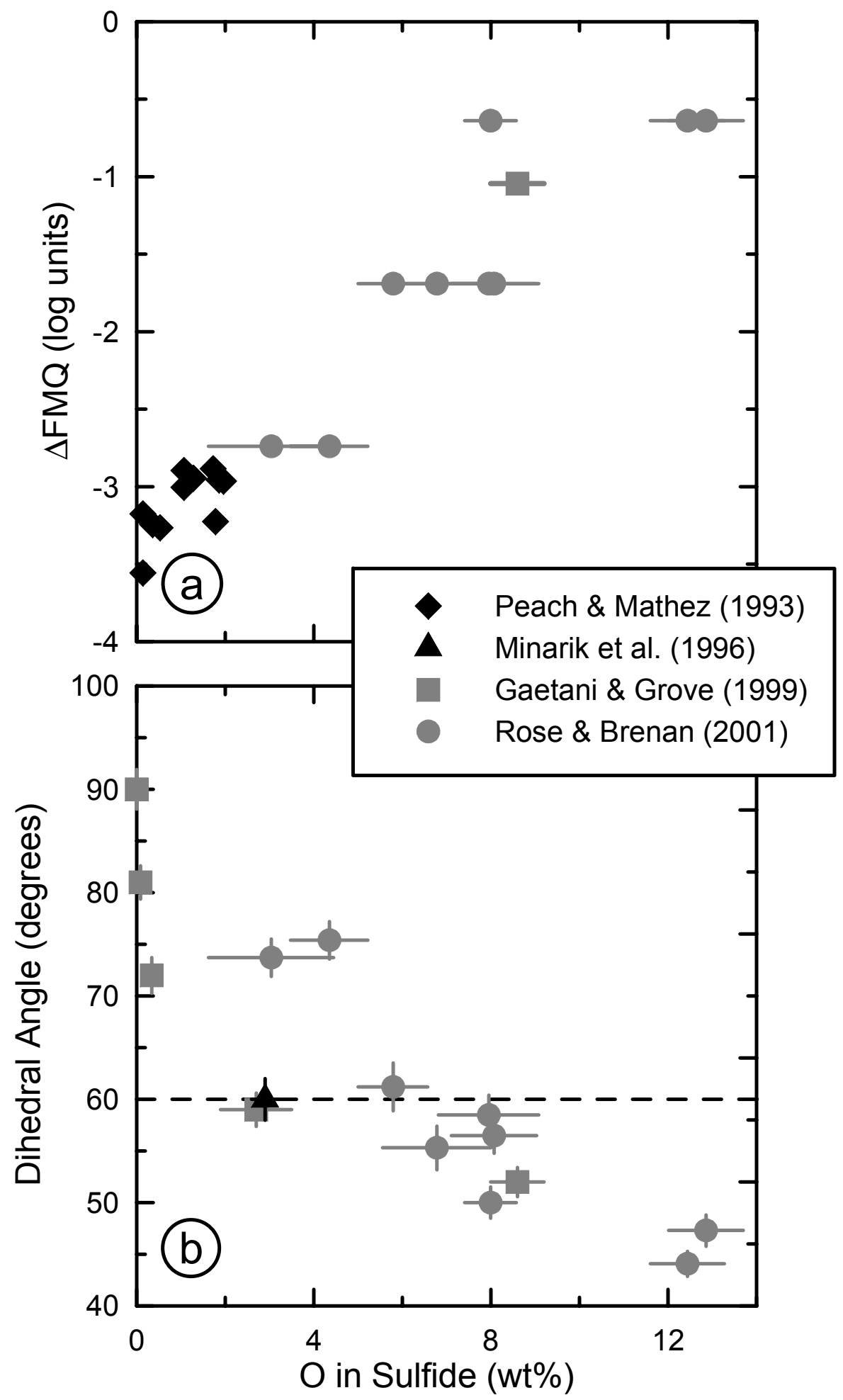



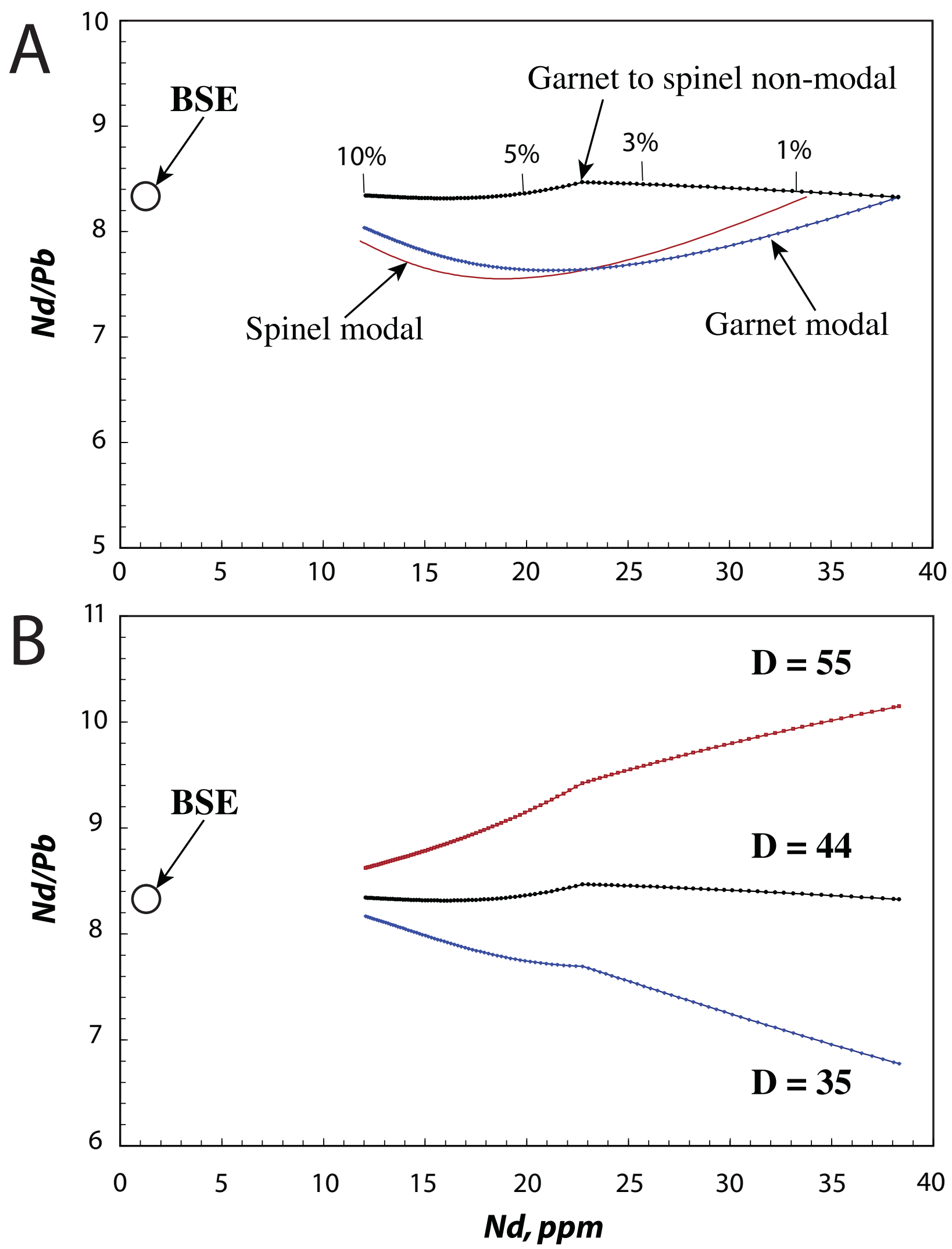
Table 1. Parameters for aggregated fractional melting models

\begin{tabular}{|c|c|c|c|c|c|c|}
\hline & Cpx & Opx & Olivine & Spinel & Garnet & Sulfide \\
\hline Mantle mode, spinel facies & 0.180 & 0.280 & 0.4993 & 0.040 & 0 & 0.00066 \\
\hline Melt mode, spinel facies & 0.720 & 0.300 & -0.0740 & 0.050 & 0 & $0.00368 *$ \\
\hline Mantle mode, garnet facies & 0.120 & 0.220 & 0.5290 & 0 & 0.130 & 0.00066 \\
\hline Melt mode, garnet facies & 0.300 & 0.180 & 0.1000 & 0 & 0.416 & $0.00368 *$ \\
\hline Mineral/melt $\mathrm{Kd}, \mathrm{Ce}$ & 0.0858 & 0.003 & 0.0005 & 0 & 0.008 & 0 \\
\hline Mineral/melt $\mathrm{Kd}, \mathrm{Pb}$ & 0.0137 & 0.005 & 0 & 0 & 0.0034 & 45 \\
\hline Mineral/melt Kd, Nd & 0.1873 & 0.009 & 0.001 & 0 & 0.057 & 0 \\
\hline & $\mathrm{Ce}$ & $\mathrm{Pb}$ & $\mathrm{Nd}$ & & & \\
\hline \multicolumn{7}{|l|}{ Bulk Kd - Spinel Facies } \\
\hline Mantle Silicate & 0.0165 & 0.0039 & 0.0367 & & & \\
\hline Melt & 0.0626 & $0.01136^{*}$ & 0.1375 & & & \\
\hline \multicolumn{7}{|l|}{ Bulk Kd - Garnet Facies } \\
\hline Mantle Silicate & 0.0123 & 0.0032 & 0.0324 & & & \\
\hline Melt & 0.02966 & $0.00642 *$ & 0.08162 & & & \\
\hline
\end{tabular}

* Sulfide melt mode varies in model; values illustrated here based on 38 wt. \% S in sulfide and $1400 \mathrm{ppm} \mathrm{S} \mathrm{in} \mathrm{S-}$ saturated melt. Melt $\mathrm{Kd}$ for $\mathrm{Pb}$ varies with melt mode and sulfide partition coefficient (here shown $=45$ ).

References for mantle and melt modes: Walter 1998; Pickering-Witter and Johnston 2000; Wasylenki et al. 2003; Kelemen et al., 2004.

References for experimental mineral-melt partition coefficients: Hart and Dunn 1993; Kelemen et al. 2004; Hauri et al. 1994; Lundstom et al. 1998; Salters et al. 2002; Tatsumoto et al. 1992; Keshav et al. 2005; Schmidt et al. 1999.

References for natural mineral-mineral partition coefficients: Meijer et al. 1990; Tatsumoto et al 1992; Carignan et al 1996; Witt-Eickscen and O'Neill 2005; Ionov et al 2006. 